\title{
Bibliometrics and Research Data Management Services: Emerging Trends in Library Support for Research
}

\author{
Sheila Corrall, Mary Anne Kennan, and Waseem Afzal
}

\begin{abstract}
Developments in network technologies, scholarly communication, and national policy are challenging academic libraries to find new ways to engage with research communities in the economic downturn. Librarians are responding with service innovations in areas such as bibliometrics and research data management. Previous surveys have investigated research data support within North America and other research services globally with small samples. An online multiple-choice questionnaire was used to survey bibliometric and data support activities of 140 libraries in Australia, New Zealand, Ireland, and the United Kingdom, including current and planned services, target audiences, service constraints, and staff training needs. A majority of respondents offered or planned bibliometrics training, citation reports, and impact calculations but with significant differences between countries. Current levels of engagement in data management were lower than for bibliometrics, but a majority anticipated future involvement, especially in technology assistance, data deposit, and policy development. Initiatives were aimed at multiple constituencies, with university administrators being important clients and partners for bibliometric services. Gaps in knowledge, skills, and confidence were significant constraints, with near-universal support for including bibliometrics and particularly data management in professional education and continuing development programs. The study also found that librarians need a multilayered understanding of the research environment.
\end{abstract}

\section{INTRODUCTION}

The purpose of the academic library has traditionally been presented as supporting the curriculum and scholarship of its parent institution. 
The mission of university libraries in the contemporary digital world continues to be characterized as supporting learning and research activities (Gumpenberger, Wieland, \& Gorraiz, 2012), and the dual functions of contributing to instruction and contributing to research tend to feature equally prominently in the published mission statements of research libraries (Aldrich, 2007). However, the service environment of academic libraries has changed radically, as a result of developments in technology, automation of operations, diversification of media, reduced purchasing power, and evolving scholarly communication (Ball \& Tunger, 2006). Library support for research has traditionally revolved around information discovery, collection development, and some elements of information management (Auckland, 2012), but the shift from print to electronic materials has made the library and its services virtually invisible to many faculty and other researchers, so they are "perceived by users to be more geared to supporting teaching and learning activities" (Bent, Gannon-Leary, \& Webb, 2007, p. 82).

Institutional administrators have disputed the use of subject librarians in the Google age (Jones-Evans, 2005); others have questioned the continued value of large academic libraries in hard times (Bourg, Coleman, \& Erway, 2009), and many such libraries have suffered staffing cuts since the economic downturn of 2008 (Nicholas, Rowlands, Jubb, \& Jamali, 2010). In consequence, as observed by Wood, Miller, and Knapp (2007, p. 3):

Academic libraries are in trouble ... They have been edged out of the top spot as the "go-to" place for virtually all aspiring researchers by the delicious (if deceptive) convenience and immediacy of the Web. Worse yet, some funding entities now view academic libraries more as bottomless pits than as what economists call a "self-evident good."

Libraries have responded to the situation energetically by launching multiple efforts to prove their worth; evaluation of libraries and assessment of the impact of their services has become a growth industry in recent years (Heath, 2011; Mays, Tenopir, \& Kaufman, 2010; Oakleaf, 2010; Town, 2011). The roles of libraries and librarians in supporting research have received particular scrutiny, especially in the United Kingdom, with a notable focus on engagement with e-research developments (Auckland, 2012; Bourg et al., 2009; Lyon, 2012; MacColl \& Jubb, 2011; RIN, 2007, 2011; Webb, Gannon-Leary, \& Bent, 2007; Young \& Lund, 2008).

Library responses to the challenges vary. Holland (2006, p. 141) argues that "the Subject Librarian who has a broad knowledge of the organizational context in which research is undertaken, who combines this with knowledge of the information sources in the appropriate subject domain and who is skilled in one to one consultations is well placed to provide the informed individual support that researchers need." However, CottaSchønberg (2007) reports that his library has moved away from subject- 
specialist roles to general information specialists and stopped recruiting staff with a library-school education and/or relevant subject degree to research librarian positions. Other libraries are moving toward more specialized forms of support: several U.K. research universities employ dedicated research support librarians (Young \& Lund, 2008), while Fonseca and Viator (2009, p. 81) see the way forward for academic librarians as "reinventing themselves as both subject/discipline and research methods experts," supporting a current trend of embedding specialist library support in disciplinary or project settings, characterized as embedded librarians, informationists, or information specialists/liaison librarians in context (Carlson \& Kneale, 2011; Freiburger \& Kramer, 2009; Shumaker, 2012).

Ball and Tunger (2006, p. 563) argue that libraries need to cease resembling museums and become efficient "business enterprises." Drummond and Wartho (2009, p. 78) describe similar thinking in Australia, where the University of New South Wales Library adopted a "business model" for its restructure, creating a new Information Services Department that includes a Service Innovation Unit and Service Development Unit alongside an Academic Services Unit, which includes a Research Impact Measurement Service. This reflects a general trend in universities away from the traditional reference desk to more flexible service models, with "Information Services" replacing "Reference Services" as the most common name for the relevant department (Burke, 2008, p. 273). MacColl (2010, pp. 152, 161) describes the shift in terms of how "the research environment reconfigures the library," also commenting on the interesting move in the United Kingdom by the University of Leicester to recruit "a professional bibliometrician, who will be based in the library" but noting that the University sought "a research statistician as opposed to a librarian-turned-bibliometrician." Pan and Breen (2011) characterize library involvement in bibliometrics as "higher end researcher support."

The introduction of performance-based allocation of research funding has been a key driver of bibliometric activity in France, Germany, Switzerland, Scandinavia, and the United States, leading to renewed interest in bibliometrics as "an instrument of science management" and a growth opportunity for librarians (Ball \& Tunger, 2006, p. 564). Pendlebury (2008) lists more than twenty countries worldwide that regularly use bibliometric reports or "science indicators studies" to evaluate research performance and inform resource allocation. In Australia, New Zealand, and the United Kingdom, periodic national assessments of the quality of research undertaken in universities are at least partly determined or informed by bibliometric indicators (Adams, 2007; Gibbs \& Sergeant, 2009; Joint, 2008; MacColl, 2010). The 2006 announcement of the Australian Research Quality Framework (RQF) was instrumental in the development of innovative bibliometric support services by libraries at the University of New South Wales and University of South Australia 
(Drummond \& Wartho, 2009; Gibbs \& Sergeant, 2009). The Research Excellence Framework (REF), the United Kingdom's assessment exercise, is the main motive for researchers seeking bibliometric support from the University of Warwick Library (Delasalle, 2012).

Another driver for library involvement in bibliometrics is the need to find new ways of adding value in the current environment (Ball \& Tunger, 2006; Hendrix, 2010). Librarians have recognized that faculty are also being challenged to prove their worth by providing evidence of the value of their scholarly contribution and that "the expertise of librarians can be used to help our faculty . . . achieve success in their tenure process" (Kear \& Colbert-Lewis, 2011, p. 470). According to Roemer and Borchadt (2012, p. 596), "many librarians have stepped forward to help [faculty] negotiate the landscape of both traditional impact metrics . . . and emerging Webbased alternatives."

National and international policy developments related to advances in e-research (networked data-intensive science) have similarly created opportunities for libraries to create value by extending their stewardship and service activities to the management and sharing of research datasets as an increasingly vital dimension of the global research knowledge base. In addition to building on library engagement with institutional repositories and open access (Macdonald \& Uribe, 2008; Walters, 2009), numerous synergies have been identified with existing professional practices in collection development and service delivery, and librarians have accordingly been involved in steering committees and working groups of official bodies in Australia, North America, and Europe (Corrall, 2012). Commentators within and beyond the library community have encouraged libraries to assume a central, strategic role within their institutions (Hey \& Hey, 2006; Lewis, 2010; Lyon, 2012; Swan \& Brown, 2008), although others have flagged the need for more specialized domain knowledge and technical know-how, sourced from across the library, to support endto-end engagement with research workflows (Garritano \& Carlson, 2009; Gold, 2007; Henty, 2008; Hswe \& Holt, 2011).

The ambiguity surrounding the roles and specific responsibilities of libraries, researchers, and others involved in the research cycle in managing digital data and other outputs is problematic (Lewis, 2010; Lyon, 2007; Pryor \& Donnelly, 2009; RIN, 2007). Librarians in both the United Kingdom and United States have received mixed messages from researchers about the value of their support services. A RIN (2007) report revealed conflicting views among researchers, librarians, and library directors on the relative importance of suggested future roles for librarians, with library staff attaching more importance than researchers to subject expertise, information literacy teaching, metadata management, and copyright advice, although there was more consensus on library responsibility for custody of special collections, institutional repository 
management, and e-resource administration. An Ithaka survey found the library's role in e-resource procurement was increasingly valued, but faculty were unlikely to consult a librarian in person, visit library service points, or search online catalogs (Schonfeld \& Housewright, 2010). Research in the United Kingdom and United States concluded that "researchers have little interest in the support services libraries have built for them in recent years, yet they are aware of support needs that are not being met" (MacColl \& Jubb, 2011, p. 10).

Libraries in the United States have been quicker than elsewhere in responding to the changing research landscape. The Massachusetts Institute of Technology (MIT) Libraries "created a research group in 2002 to design and develop tools to support discovery, offering a new vision of the role of the librarian on campus as research partner and innovator," strengthened research partnerships on campus, and redefined subjectspecialist roles to shift their emphasis from collections and reference to "services and tools" (Duranceau, 2008, p. 256). A survey by the Association of Research Libraries in 2009 found twenty-one libraries already providing infrastructure or support services for e-science, with another twentythree intending to do so (Soehner, Steeves, \& Ward, 2010). The National Science Foundation (NSF) announcement that researchers must submit data management plans with their grant applications prompted another surge of library initiatives around data management planning (Hswe \& Holt, 2011).

Relevant developments have taken place in other countries, though to a lesser extent: Auckland (2012) confirms that research libraries are shifting their focus from traditional forms of support for researchers toward data management and curation, and also bibliometrics, citing examples from Australia, New Zealand, the United Kingdom, and Ireland, among other countries; however, she also notes significant skills gaps and shortages among U.K. research libraries that may hinder further development. There has been no comprehensive study of research data management services in academic libraries outside North America, nor any systematic investigation of library involvement in bibliometric support, representing another significant opportunity for strategic service innovation. Within the context outlined, the present study sought to investigate and illuminate issues surrounding the development of research services related to bibliometric support and research data management in the academic libraries of Australia, New Zealand, Ireland, and the United Kingdom. The study population was selected because of growing evidence of activity in the area that required substantiation and because of its accessibility to the research team through established professional networks.

The gaps in previous research suggest the present study has much to contribute in terms of baseline data and areas for future research and development, including education and training to meet needs arising from 
new roles for librarians and different relationships with researchers and other stakeholders. The research reported here aimed to discover the following:

- What specialist research support services are academic libraries offering and planning to offer in the future in Australia, Ireland, New Zealand, and the United Kingdom?

- Are libraries and library staff constrained in providing specialist research support services?

- Do library staff require additional education, training, and support in their research support roles?

- How might library and information science (LIS) schools respond to the evolving role of research support services in academic and research libraries?

The next section reviews the literature that formed the background to the present study and informed the design of the research instrument. The subsequent section explains the design of the study and composition of the sample, followed by presentation of the main findings and observations on their significance. The conclusion then summarizes key findings and suggests lines of inquiry for future work.

\section{Literature ReVIEW}

\section{Bibliometric Support Services}

Library engagement in bibliometric activities can be traced back to the 1970 s, when the focus was on using citation analysis and related techniques in collection building, management, and assessment, especially for journals (Baughman, 1977; Broadus, 1977; Drott, Mancall \& Griffith, 1979; Line, 1978; Warr, 1983). The focus lately has shifted from informing library decisions on selection and evaluation of printed materials and electronic resources to supporting the analysis and assessment of research output at individual, departmental, and institutional levels (Gumpenberger et al., 2012), although traditional applications to collection development have continued in the United States (Beck \& Manuel, 2008) and Australia (Davis, Wilson, \& Horn, 2005). Drummond and Wartho (2009) cite reports of recent library initiatives in bibliometric support for research in Australia, Austria, Germany, Lebanon, South Korea, and the United States. Pan and Breen (2011) describe an innovative national collaboration in Ireland, Measuring your Research Impact (MyRI), that has produced an open-access bibliometrics toolkit to support efforts of librarians in user awareness and training.

Additional evidence of current professional interest in bibliometrics can be found in studies presented at mainstream professional conferences (Adams, 2007; Gibbs \& Sergeant, 2009; Pan \& Breen, 2011) and specialist bibliometrics events (Gumpenberger etal., 2012), Internet resource guides 
published in practitioner periodicals (Kear \& Colbert-Lewis, 2011; Roemer \& Borchadt, 2012), and comprehensive LibGuides produced by individual libraries (e.g., Arizona State University, 2012; Macquarie University, 2012; University of Pittsburgh, 2012), along with articles calling for librarians to assume a more strategic role in research evaluation and its management (Herther, 2009; Joint, 2008; MacColl, 2010). Gumpenberger et al. (2012, pp. 174-175) assert that bibliometrics and scientometrics are "ideal fields of activities for modern academic libraries," offering opportunities "to develop and provide innovative services for both academic and administrative university staff" and to engage in research and development, conferences, and other scholarly activities. Their rationale, echoing Ball and Tunger (2006), is based on librarians' competence in handling bibliographic data and electronic databases, and their institutional position as independent interdisciplinary units; Ball and Tunger (2006) also observe that neither science managers and their staff, nor the scientists themselves, have the know-how and tools to perform bibliometric analyses.

However, Ball and Tunger (2006, p. 565) assert that information professionals have "taken up this business area much too late." Herther (2009, p. 368) is similarly critical, arguing that librarians need to engage with research evaluation and citation analysis at a higher level, "exploring how we might fulfill some of our users' more complex needs and interests," for example by investigating the coverage of citation databases and the reliability of quality indicators and working with vendors to improve search and retrieval features and enhance data manipulation and integration capability - a strategy successfully adopted by the University of Vienna Library in three development partnerships with vendors (Gumpenberger et al., 2012). MacColl (2010, p. 166) also calls for a more proactive, strategic stance, that moves beyond bibliometric administrative or support services, stating that libraries need to "reassert their role in respect of scholarly knowledge ... as the main authority on the campus" and "the only neutral scholarly actor" by exploiting and promoting their expertise in bibliometrics, copyright, licensing, publishing, open access, and scholarly dissemination.

Published case studies provide further insight into new services launched since 2003 by academic and research libraries in Germany (Ball \& Tunger, 2006), Australia (Drummond \& Wartho, 2009; Gibbs \& Sergeant, 2009), and the United States (Hendrix, 2010), as well as a whole department devoted to bibliometrics in Austria (Gumpenberger et al., 2012), and smaller scale or one-off activities and undertakings in the United Kingdom (Delasalle, 2012) and United States (Amos et al., 2012; Bennett, Leonard, \& Wrublewski, 2012). Activities undertaken range from impact analysis (described as "response analysis" by Ball and Tunger, 2006), using quality indicators such as the $h$-index, Egghe's g-index, or alternative calculations 
for humanities and social science researchers (Bennett et al., 2012; Delasalle, 2012: Drummond \& Wartho, 2009; Hendrix, 2010), to trend analysis for scientific topics over time (Ball \& Tunger, 2006; Drummond \& Wartho, 2009), in addition to delivery of training and education for individuals and groups, which at the University of Vienna includes curricular courses for doctoral students and LIS students (Gumpenberger et al., 2012).

Services can be targeted at individuals, academic units, or institutional level and marketed in various ways for internal or external purposes: for example, advice on publishing strategies, especially for early-career researchers, and support for job applications or a salary/faculty review (Delasalle, 2012; Drummond \& Wartho, 2009); "tenure metrics" workshops for faculty (Hendrix, 2010); standard sets of research impact measures for "grant application statements" (Drummond \& Wartho, 2009); output comparisons for benchmarking with peer groups at different institutions (Ball \& Tunger, 2006; Bennett et al., 2012; Delasalle, 2012; Drummond \& Wartho, 2009); analyzing publishing patterns and usage data to inform a scholarly communications program at the University of Utah (Amos et al., 2012); finding a university's most cited papers and providing $h$-indices for the most cited researchersfor institutional promotional materials (Hendrix, 2010); and support for national research assessment exercises (Delasalle, 2012; Drummond \& Wartho, 2009), including compiling whole-career citation counts for researchers across the university (Gibbs \& Sergeant, 2009). Practitioners have identified additional benefits of bibliometrics work in informing library collection development, facilitating institutional repository growth and improving metadata quality but also comment on the significant staffing effort involved (Amos et al., 2012; Drummond \& Wartho, 2009; Gibbs \& Sergeant, 2009; Hendrix, 2010).

\section{Education for Bibliometric Support Services}

Reflecting the historical use of bibliometrics in libraries, early discussion of its teaching in library schools similarly identifies collection development, weeding, and journal evaluation as significant examples of its practical application. Shrader (1981) reports few courses on the subject in American library schools and minimal coverage in library science research methods textbooks. However, his proposed syllabus for a master's course in bibliometrics devotes only two of fifteen units to applications for professional practice, with his main concern apparently to educate librarians as researchers and make them more numerate and competent in handling quantitative data. In contrast, Ungern-Sternberg (1998, p. 76) advocates teaching bibliometrics as it is "becoming more important as a basis for collection development in research libraries," proposing a course based on a real library problem: local collection development in an interdisciplinary field. Her proposed course similarly introduces students 
to the methods and results of seminal theorists but in parallel with empirical work on their own projects, applying theories and techniques (e.g., Bradford's law, bibliographic coupling, and co-word analysis) to dayto-day work in libraries, showing how different methods can be used for key stages of the collection development process (planning, implementation, and evaluation).

More recently, Davis et al. (2005, pp. 199, 209) report that "no Australian university has courses that teach informetric methodologies" and also argue that informetric research methodology "needs to be taught in research course components to all students taking information-related degree programs," but again largely on the basis of its proven value in more traditional applications within libraries, such as collection management related to journal provision and use. Zhao (2011, p. 1) reports that there is still "very limited coverage" of bibliometrics in contemporary LIS education in North America, having found only thirteen courses with "bibliometrics," "informetrics," or "webometrics" in their titles among fiftyfive schools with programs accredited by the American Library Association, with the subject mostly taught as a small part of research methods courses (though citation databases are covered in information-searching courses). However, her case for bibliometrics courses moves beyond the previous focus on collection management and instead recognizes present opportunities for bibliometrics and "bibliometricians" to form the basis of new, innovative "value-added information services" in libraries, noting as evidence the hiring of such bibliometric specialists by "many university libraries in Europe" (Zhao, 2011, p. 1).

Zhao (2011, p. 1) also argues that bibliometrics research is "quite strong as well among research valued and conducted by librarians in academic and research libraries" and points out an additional disconnect here, between LIS research and LIS education: bibliometrics is a prominent research area in information science and distinctive in being a specialty developed within information science that has been successfully exported to other domains that have taken up its methods, in contrast to research methods imported from other fields and applied to LIS. This disconnect is also evident in continuing limited coverage in LIS research methods textbooks: Pickard (2007) and Wildemuth (2009) omit bibliometrics completely, while Connaway and Powell (2010) devote only two pages to the subject; both Beck and Manuel (2008) and Wallace and Van Fleet (2012) devote a whole chapter of their practitioner-oriented research methods texts to the topic, but library applications in institutional research evaluation are not discussed. Fortunately, texts covering evaluative bibliometrics aimed specifically at librarians are becoming available (e.g., De Bellis, 2009). 


\section{Research Data Management}

Library participation in research data management has a much shorter history, although prior experience in engaging with social science data archives and geospatial data resources offers models that can be adopted for other domains. Macdonald and Martinez (2005) trace the history of data librarianship in the United Kingdom, showing how practitioners have moved beyond supporting dataset discovery and desktop analysis to repository, reference, and education services. A special issue of Library Trends on geographic information systems (GIS) developments in the United States provides insights into formulating a data management and distribution policy for the Cornell University Geospatial Information Repository (Steinhart, 2006), geospatial data collection building at Harvard University (Florance, 2006), and developing specialized support services, including GIS instruction, project consultation, and software training at the University of Kansas (Houser, 2006). At MIT, a data librarian position with a social sciences focus was established around 2004 and then progressed to working on open-data issues on campus (Duranceau, 2008).

Case studies of library engagement in research data management began to emerge in 2008, when Library Trends published a special issue on institutional repositories that described library efforts to include research datasets in their archiving at Johns Hopkins University, Purdue University, and the University of Minnesota (Choudhury, 2008; Delserone, 2008; Witt, 2008). Reports of data management initiatives taken at other libraries have followed: for example, in America, the Georgia Institute of Technology (Walters, 2009), MIT (Gabridge, 2009), University of Houston (Peters \& Dryden, 2011), University of Oregon (Westra, 2010), and University of Colorado Boulder (Lage, Losoff, \& Maness, 2012); in Australia, Queensland University of Technology (Thomas, 2011) and the University of Sydney (Brownlee, 2009); in Asia, the Hong Kong University of Science and Technology (Wong, 2009); and in Europe, the University of Edinburgh (Rice \& Haywood, 2011). Soehner et al. (2010) also provide case studies of Cornell University, the University of California, San Diego, and the University of Illinois at Chicago, in addition to updates on developments at Johns Hopkins, MIT, and Purdue.

Further evidence of the mainstreaming of research data management in the library field is shown by the publication of books on the subject aimed specifically at library and information professionals, including collections of papers on The Data Deluge (Marcum \& George, 2010) and Managing Research Data (Pryor, 2012), in addition to a "how-to" manual on Digital Curation (Harvey, 2010). The role of libraries and librarians in managing research data also features in chapters of recent texts on the future of academic libraries (e.g., Carlson \& Garritano, 2010; Lewis, 2010; Swan, 2011). Evidence from the literature shows that librarians are building on existing practices across the libraries, in areas from the 
reference interview and information literacy to digital preservation and repository development, as well as developing new models of practice, especially in relation to assessing data curation needs: for example, librarians at Purdue have used "data interviews" to develop Data Curation Profiles of campus researchers, while librarians at Boulder have created "personas" of researchers that can potentially be used at other universities (Lage et al., 2012)

Common themes characterizing the activities of librarians in response to the research data challenge include conducting assessments of needs among their user communities (Delserone, 2008; Gabridge, 2009; Lage et al., 2012; Peters \& Dryden, 2011; Rambo, 2010; Rice \& Haywood, 2011; Thomas, 2011; Walters, 2009; Westra, 2010; Witt, 2008); exploring the deposit of research datasets in institutional repositories (Brownlee, 2009; Choudhury, 2008; Delserone, 2008; Gabridge, 2009; Rice \& Haywood, 2011; Walters, 2009; Witt, 2008; Wong, 2009); forming groups within the library to progress initiatives (Delserone, 2008; Gabridge, 2009; Peters \& Dryden, 2011; Rambo, 2010; Walters, 2009; Witt, 2008); creating new library positions, notably with an interdisciplinary research focus (Delserone, 2008; Walters, 2009; Witt, 2008); developing strategic alliances and partnerships with other campus organizations, such as research offices and/or technology services (Delserone, 2008; Schottlaender, 2010; Witt, 2008); providing guidance on data management planning (Gabridge, 2009; Rice \& Haywood, 2011; Thomas, 2011); and formalizing research relationships with academic units (Choudhury, 2008; Witt, 2008).

\section{Education for Research Data Management}

The educational preparation of professionals for RDM roles has been a recurring theme in high-level reports (Friedlander \& Adler, 2006; HLG, 2010; NSF, 2007), as well as in articles and reports specifically examining roles and/or skills (Henty, 2008; Lewis, 2010; Lyon, 2007; Pryor \& Donnelly, 2009; Swan \& Brown, 2008). The situation here is complicated by consideration of the education and training needs of researchers alongside all those potentially involved in curating or managing their data - within a research group, library, or computing/technology centerand debate around who should provide the education and training. The idea of educating future researchers by incorporating data management into undergraduate and graduate curricula as a logical extension of information literacy emerged from the Skills for eResearch Project in Australia (Henty, 2008). In the United Kingdom, Lewis (2010) suggests roles for library staff in developing the data literacy/data management skills of both graduate research students and undergraduates but also flags the need for the library workforce to develop additional skills to fulfill these responsibilities (via short courses and/or specializations within LIS master's programs); interestingly, he also suggests short courses 
for researchers interested in RDM roles and master's programs for data scientists/managers intent on careers in large data centers.

Pryor and Donnelly (2009) note the breadth and depth of the technical, contextual, and other competencies required to varying degrees by different players in the emerging $\mathrm{RDM}$ landscape; their review of academic programs in the United Kingdom, Ireland, Sweden, and the United States found only one digital curation course in the United Kingdom and no programs or concentrations on data management/curation, in contrast to a master's in digital curation at Luleå University of Technology (Sweden), a master's of LIS specialization in data curation at the University of Illinois at Urbana-Champaign, and two relevant curriculum development projects at the University of North Carolina at Chapel Hill. Development of courses specifically designed to prepare LIS professionals for roles in RDM is now more evident but is occurring to varying extents in different countries, with external funding a significant factor in stimulating innovation; in the United States, IMLS has invested a massive $\$ 9$ million in RDM education and capacity building as of the 2011 funding cycle (Keralis, 2012). Harris-Pierce and Liu (2012) found LIS schools in North America were increasingly responding to the demands of the "data deluge," with sixteen of fifty-two programs currently offering courses on data curation/data management, although eight were "special topics," whose future status is unclear; more significantly, seven schools are offering concentrations or specializations in the subject, mostly developed with support from IMLS grants. Varvel, Bammerlin, and Palmer (2012) found seven master's, four certificates, and ten concentrations with a data focus at seventeen of sixtythree schools investigated.

Recent IMLS-funded innovations include a proposed four-course graduate academic certificate in digital curation and data management at the University of North Texas (Harris-Pierce \& Liu, 2012; Keralis, 2012), which exemplifies an emerging trend within LIS programs to offer RDM education for other disciplines; the new certificate is aimed at retraining librarians, but one course on cyberinfrastructure fundamentals is open to graduate students from other disciplines (Keralis, 2012; University of North Texas, 2011). Other examples of reaching out to wider audiences include a five-day course on RDM for graduate students in all disciplines at the University of Wisconsin-Madison (Harris-Pierce \& Liu, 2012) and a data information literacy course for science and engineering students offered by a library partnership led by Purdue University (Keralis, 2012).

There is noticeable diversity in the content of data management/ curation courses, which is reflected in the variety of course and specialization titles. Harris-Pierce and Liu (2012) recommend schools collaborate to define optimal course objectives and learning outcomes; such collaboration should arguably include academic libraries (Lewis, 2010) and could be extended to technology services and graduate schools 
or others responsible for researcher development (Pryor \& Donnelly, 2009). While "digital curation" and "digital stewardship" remain common labels, the word "data" is more prominent now than previously, but much data-related content in LIS courses has come from revision of existing courses (as an evolution of digital library education) rather than from new course development (Varvel et al., 2012).

Other themes include the need to upskill the existing library workforce, in addition to educating new entrants (Lewis, 2010; Ray, 2009) and the need for formal training "to be closely associated with real-life situations and practice" (Pryor \& Donnelly, 2009, p. 166). Many IMLS projects have been designed to benefit both students and practitioners, such as through annual training institutes at the universities of Illinois (Renear, Dolan, Trainor, \& Muñox, 2010) and North Carolina (Keralis, 2012). The focus on experiential learning is manifest in the internships and other field experiences provided in many of the new or revised specialized programs, such as at Arizona (Fulton, Botticelli, \& Bradley, 2011), Illinois (Ray, 2009; Keralis, 2012), Michigan (Yakel, Conway, Hedstrom, \& Wallace, 2011), and Syracuse (Qin et al., 2010; Stanton et al., 2011).

\section{Research Design}

Given the exploratory nature of the research, which was seeking to understand what is actually happening in academic libraries in the four countries, what their plans are with regard to future research services, and what may be the implications for education and practice, a survey method administered in the form of a questionnaire was selected as an appropriate strategy (Pickard, 2007). Furthermore, with a questionnaire, data can be collected spontaneously, inexpensively (Whitten \& Bentley, 2007), and quickly (McNeill \& Chapman, 2005), which was particularly important as the research team was concerned to obtain and share usable results within a timeframe that would enable both educators and practitioners to respond effectively to emerging needs. An online survey instrument enabled the researchers to approach a large number of libraries in diverse locations (Case, 2012) to elicit exploratory data about what they are doing and planning.

A questionnaire reflecting the purpose and objectives of the study was developed using information gained from the literature on the subject and contacts in the field. It was submitted to the funding institution for ethics approval, which was granted in December 2011. The instrument was pilot tested with four senior academic librarians in research support roles from four different institutions in Australia and the United Kingdom in January 2012 and then modified in the light of feedback received from the pilot. The pilot confirmed that the questionnaire took no longer than fifteen to twenty-five minutes per participant to complete. It contained thirty-five questions, mainly multiple-choice, with text-boxes enabling participants to 
give answers other than the prespecified responses. The questionnaire was arranged in four main sections:

- About you and your organization

- Research support services - Bibliometrics

- Research support services - Research data management

- Research support services - Future plans

The sample of academic libraries was identified through the membership lists of their respective national organizations: the Council of Australian University Libraries (CAUL); the Consortium of National and University Libraries (CONUL) in Ireland; the Council of New Zealand University Librarians (CONZUL); and the Society of College, National and University Libraries (SCONUL) in the United Kingdom. The questionnaire was administered using the SurveyMonkey tool and distributed in February 2012 via e-mail invitations to participate that outlined the aims of the study and contained a link to the web-based survey instrument. E-mail messages were personally addressed to carefully targeted contacts in an effort to maximize the response rate. Target respondents were identified from publicly available library web pages as being responsible for research support services. If it was unclear which role was responsible for research support services, the invitation to participate was sent to the university librarian/director of library services, with a request to pass it on to an appropriate member of staff. Nonrespondents were sent personalized reminders during March 2012.

One hundred and seventy-four responses were received from 219 potential respondents. The data were cleansed of thirty-one empty records (responses that contained no answers beyond the first four demographic fields) and three duplicate records (two responses from the same institution), thirty-four records in total. Of the duplicates, the response retained from each institution was the most complete response. One hundred and forty valid records were analyzed. As shown in table 1, valid response rates varied between countries: the highest response rates came from the smallest countries, with Ireland and New Zealand recording 100 percent response rates, closely followed by Australia with a 89.7 percent response. While the 54.9 percent response from the United Kingdom is out of line with the higher response rates for the other countries, it is still a good response. (This apparent disparity warrants further investigation but may be partly explained by the different profiles of the membership organizations used to construct the sample; for example, the current SCONUL membership includes a significant proportion of higher-education colleges that do not have a strong research focus.)

\section{FINDINGS}

To facilitate cross-country comparisons, the results are presented here as percentages rather than numbers, to ameliorate the order of 
Table 1. Library response rates by country

\begin{tabular}{lcccrc}
\hline & Australia & Ireland & NZ & UK & Total \\
\hline Number of institutions & 39 & 9 & 8 & 163 & 219 \\
Number of responses & 35 & 9 & 8 & 88 & 140 \\
$\%$ response rate & 89.7 & 100 & 100 & 54.9 & 63.9 \\
\hline
\end{tabular}

magnitude differences between the population sizes and response rates of participating libraries in the four countries surveyed. Percentages are rounded (to one decimal point) and calculated for each country on a question-by-question basis in relation to the number of respondents answering the particular question or subquestion, as all questions were optional and not all respondents answered each question. For simplicity, each survey participant is referred to as a "library," even though sometimes it is a broader organization, such as a library system or an information service.

\section{Bibliometric Support Services}

Participants were asked about their current and planned bibliometrics services, including the following types of bibliometrics services identified through the literature, library contacts, and questionnaire pilot testing as areas of concern for libraries and researchers:

- Bibliometrics training/bibliometrics literacy

- Citation reports

- Calculations of research impact

- Grant application support

- Evaluation of candidates for recruitment, promotion, or tenure

- Disciplinary research trend reports

- $h$-index calculations

Currently, the majority of responding libraries in each country offers some bibliometrics services. The most common service offered is bibliometrics training or literacy, followed by citation reports and calculation of research impact. Services less frequently offered include the evaluation of candidates for recruitment, promotion, or tenure, and disciplinary research trend reports. In all of the participating countries except for the United Kingdom, calculations of research impact are a service provided by more than half of the responding libraries (more than three-quarters in Ireland), whereas in the United Kingdom, only slightly more than onefifth of respondents (22.4 percent or 19 of the 85 U.K. libraries answering the question) provide this service. Another interesting finding related to grant application support, where much higher proportions of respondents in Australia (41.2 percent or 14 libraries) and Ireland (37.5 percent or 3 
libraries) offer this service. Overall, the nine Irish libraries are currently by far the most active in providing bibliometric support, which is arguably a direct result of the groundbreaking collaborative MyRI project that produced an open access bibliometrics toolkit for user awareness and training, with funding from National Digital Learning Resources (NDLR), the Irish learning objects repository

Even though they currently offered fewer bibliometrics services, U.K. academic libraries were not planning to offer substantially more services in the foreseeable future, with the percentage of U.K. libraries identifying services as "planned" even lower than those reporting services as "offered." If we add the scores for current and planned services together to show the anticipated level of involvement envisaged in the near term, then we find that around three-quarters of Australian and almost all New Zealand and Irish libraries will be offering bibliometrics literacy training and citation reports, with a substantial majority offering research impact and $h$-index calculations, and significant numbers providing grant application support and disciplinary trend reports. However, for the United Kingdom, it is only the first two service categories (bibliometrics training and citation reports) that show a majority of responding libraries being involved. Table 2 provides a detailed percentage breakdown of current and planned bibliometric services by category and by country. (Note that the number of responses per country varied slightly for the different service categories.) When invited later to elaborate on anticipated future research support services, several libraries mentioned developing reporting tools and impact measures for their institutional repositories.

The U.K. results may seem surprising in the context of the long history there of national assessments of research quality linked to institutional funding allocations. However, the apparent low level of planned bibliometric activity among U.K. libraries may reflect the present confusion surrounding the role of bibliometrics in the 2014 REF (the national research assessment exercise). Successive reports and statements from the Higher Education Funding Council for England (HEFCE) have suggested that citation information is now likely to be less important than previously assumed. A pilot exercise to develop bibliometric indicators for the REF concluded that "Bibliometrics are not sufficiently robust at this stage to be used formulaically or to replace expert review in the REF. However there is considerable scope for citation information to be used to inform expert review" (HEFCE, 2009, p. 19). In addition, a more recent report raises further concerns about the reliability of citation data, particularly how different attributes of researchers (such as age, gender, and ethnicity) affect their citation scores, noting that "the potential role of citation information [in the REF] is still undecided (HEFCE, 2011, p. 19). Interestingly, this report issues a specific "health warning" about the use of bibliometric data, not only by national assessment panels but also 


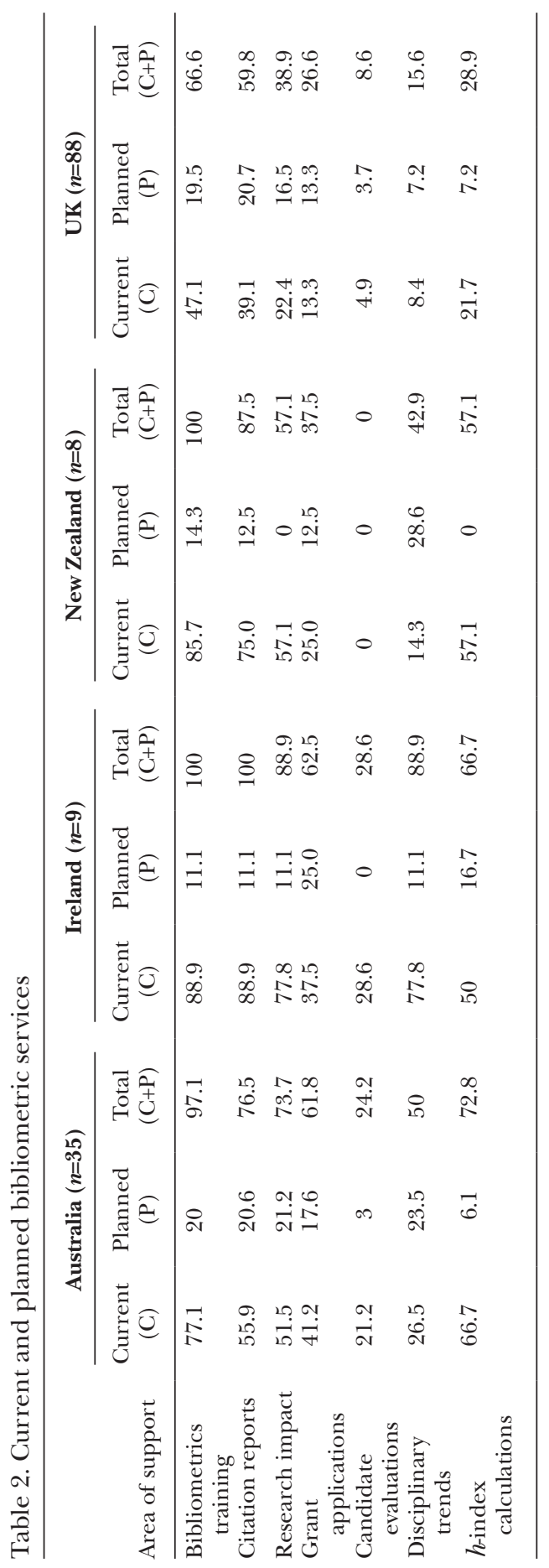


by higher-education institutions "in their business processes" (HEFCE, 2011, p. 20), particularly in the context of selecting researchers and their research outputs for the REF exercise, though this would be equally applicable in evaluating faculty for appointment or promotion.

Our analysis (shown in fig. 1) also indicates that while other business units within universities offer bibliometrics services (usually the research office or equivalent), this is much more prevalent in Australia and Ireland, where the libraries are also strong in providing such support but less so in New Zealand and, especially, in the United Kingdom. It seems then that generally research offices are not offering these services as an alternative to library support. Indeed, libraries sometimes partner with these services to provide bibliometrics services: response percentages to the relevant question showed that this is universally the case in Ireland (reported by 100 percent of libraries answering the question) and fairly common in Australia (reported by 54.3 percent of respondents) but, again, less common in New Zealand (25 percent) and the United Kingdom (27.3 percent).

However, the picture for the United Kingdom is less straightforward than elsewhere, as in response to the invitation to specify units other than research offices and academic services, respondents there identified a range of different units also offering bibliometric support, including three examples of individual academic departments, in addition to two planning offices, one group dedicated to supporting institutional preparation for the REF, and one graduate research school. This confirms

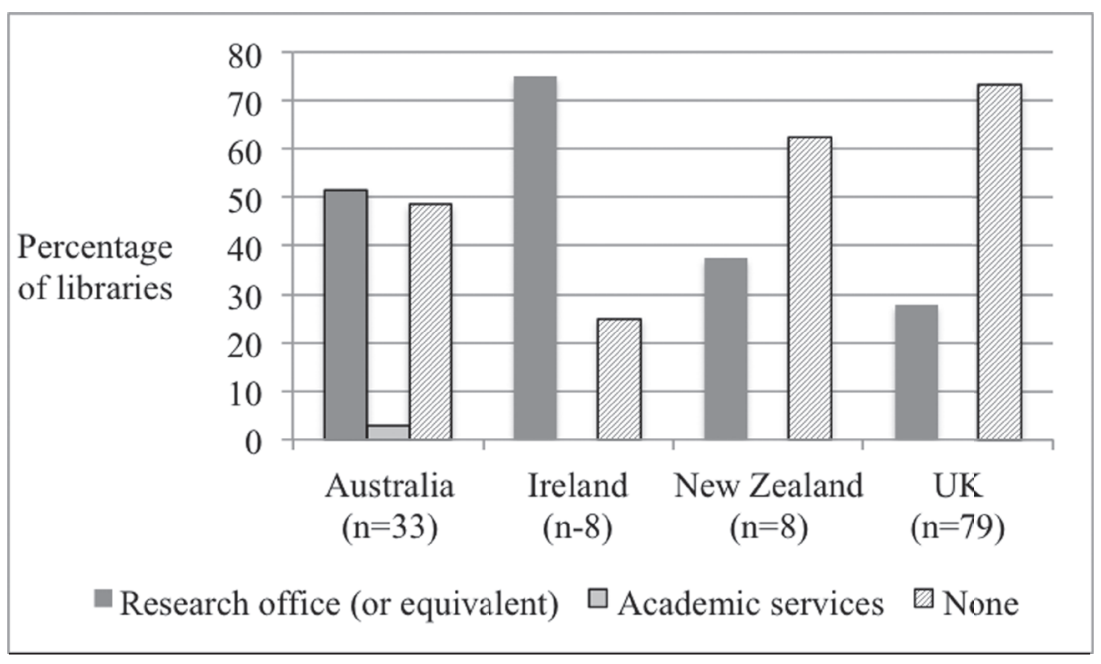

Figure 1. Other units offering bibliometric support. 
the situation described by MacColl and Jubb (2011, p. 7), who comment specifically on the varied pattern of research administration in U.K. universities, which is often characterized by a fluid mix of decentralized and centralized support, as "the approach of a new RAE/REF deadline requires an ad-hoc centralised structure to be assembled." Indeed, when invited to provide additional comments about plans for future research support services, many U.K. libraries mentioned developing bibliometric support specifically for the REF, confirming the picture presented in the literature (Delasalle, 2012; MacColl, 2010).

Our findings on bibliometric support warrant further investigation, as various questions arise that cannot easily be answered by a multiple-choice questionnaire survey-for example: Why are some services increasingly offered in all of the respondent countries except for the United Kingdom? Are there significant differences in the higher-education environment of these countries, differences in the economic conditions or academic culture, or in the nature and expectations of their academic libraries; or do these findings represent a complex interaction among all of the preceding factors?

\section{Research Data Management}

Respondents were asked about current offerings and future plans for the following RDM services identified through literature and pilot testing as areas of concern for libraries and researchers:

- Assistance to use available technology, infrastructure, and tools

- Guidance on the handling and management of unpublished research data, for example data literacy education and/or training

- Support for data deposit in an institutional repository

- Support for data deposit in external repositories or data archives

- Finding relevant external data sets

- Technical aspects of digital curation

- Developing data management plans

- Developing tools to assist researchers manage their data

- Development of institutional policy to manage data

Fewer libraries in our sample currently offer RDM services than offer bibliometric support, but, in contrast to their bibliometrics activities, U.K. libraries featured more strongly here, with a higher proportion than other countries currently offering support in two areas: assistance with technology, infrastructure, and tools; and finding external datasets. However, for the latter area, it is worth noting that the United Kingdom has a long history of data librarians helping researchers to identify external data resources (Macdonald \& Martinez, 2005). Overall, Australian libraries recorded the highest percentages of current involvement in six of the nine areas for research data management, as shown in table 3. 
RDM services represent a relatively new development in library service offerings, which is evident in the high proportion of libraries in the process of planning to offer RDM support (see table 3). This finding is interesting in its own right, as well as significant when compared with the findings pertaining to bibliometrics services. In the case of bibliometrics, a majority of the libraries in all of the four countries was currently offering these services, and thus fewer libraries were still planning to offer them in future. Because of the relatively new nature of RDM services, fewer libraries are currently offering such support and more are instead planning to offer services in the future. For example, only a small proportion of libraries were offering guidance on the handling and management of unpublished research data (none in Ireland, only two [25 percent] in New Zealand, eleven [14.3 percent] in the United Kingdom, and nine [25.7 percent] in Australia); but many more libraries were planning to offer such support in the future (37.5 percent in Ireland, 50 percent in New Zealand, 42.9 percent in the United Kingdom, and 60 percent in Australia). Only five libraries (14.3 percent) from Australia and two (25 percent) from New Zealand were not planning to offer these services, though larger percentages of Irish (62.5 percent) and U.K. (42.9 percent) libraries had no plans to do so.

Similarly, among the responding libraries, relatively high numbers were already offering support for data deposit in an institutional repository, including at least half of the respondents from Australia and Ireland, with many others planning to offer such support, bringing the anticipated percentages for all four countries into the 75 to 85 percent range. Other RDM support services, such as developing data management plans, developing tools to assist researchers with managing their data, and technical aspects of digital curation, were apparently considered quite important by the libraries and thus were on their agenda as future research support services offerings for around 40 percent or more of respondents in each case. It can be argued here that the eminence of these services among the libraries' future offerings represent more than mere responses to recent technological change; an increasing interest in data management plans and in assisting researchers with managing their data arguably illustrates the trickling down effect of the combination of economic, educational, and technological forces that are operating in the educational environment in which libraries operate.

When we add the results for planned services to the results for current RDM services (see table 3), overall, we find that such services are increasingly anticipated being offered in future. However, the United Kingdom is out of line here: while the percentages of U.K. libraries currently offering RDM support through assistance with technology infrastructure and tools (53.8 percent) and finding external datasets (41.3 percent) are relatively high, these areas form only a small part of 
the portfolio of support services thought to be needed, and even when we add their planned services to their current offerings, the plans of the U.K. libraries look disappointingly modest alongside those of their peers in other countries. Data for the other three countries indicate that support services will likely be provided in five or more of the areas specified by at least 70 percent of the libraries, whereas for the United Kingdom, this level of participation may only be achieved for three areas (technology infrastructure, institutional deposit, and policy development). Plans for RDM support also seem relatively underdeveloped in Ireland (especially in contrast to the level of participation in bibliometric support), which may reflect slower development of data management policies by national research funding bodies, in comparison with policy development in other countries. For example, the Data Management Checklist produced by University College Dublin Library (Barrett, 2012) only cites institutional policies, with no reference to national policy or guidance on RDM. Table 3 provides a detailed percentage breakdown of current and planned RDM services by category and by country.

\section{Target Users for Services}

Users occupy a central position in library and information services; their needs and information behavior influence the ways in which information services are designed, developed, and delivered. Tables 4 and 5 show that most of the libraries surveyed identified individual academic and research staff (i.e., faculty members and postdoctoral or contract researchers) as the primary current users of bibliometric and RDM services, followed by higher-degree research students (i.e., postgraduate research students), except for libraries in New Zealand, which prioritized research students in the case of RDM.

Both bibliometric and RDM services were targeted principally at individual users, but the data also reveal a strong focus on services directed at schools or other institutional groupings as academic units (e.g., faculties/colleges) to a greater extent than services aimed at the institution as a whole, although university administrations were also identified as important users (by a majority of respondents in all four countries; see table 4) of bibliometrics services, which represents a significant extension of the traditional client base for academic libraries. It is quite possible that increasingly, university administrations are using these services for institutional and/or individual performance management and/or to develop a university-specific research profile. As previously reported, Irish academic libraries are the most active in the provision of bibliometric services, closely followed by the libraries of Australia and New Zealand. Table 4 provides a detailed percentage breakdown of current and planned target users of bibliometric services by user group and by country. 


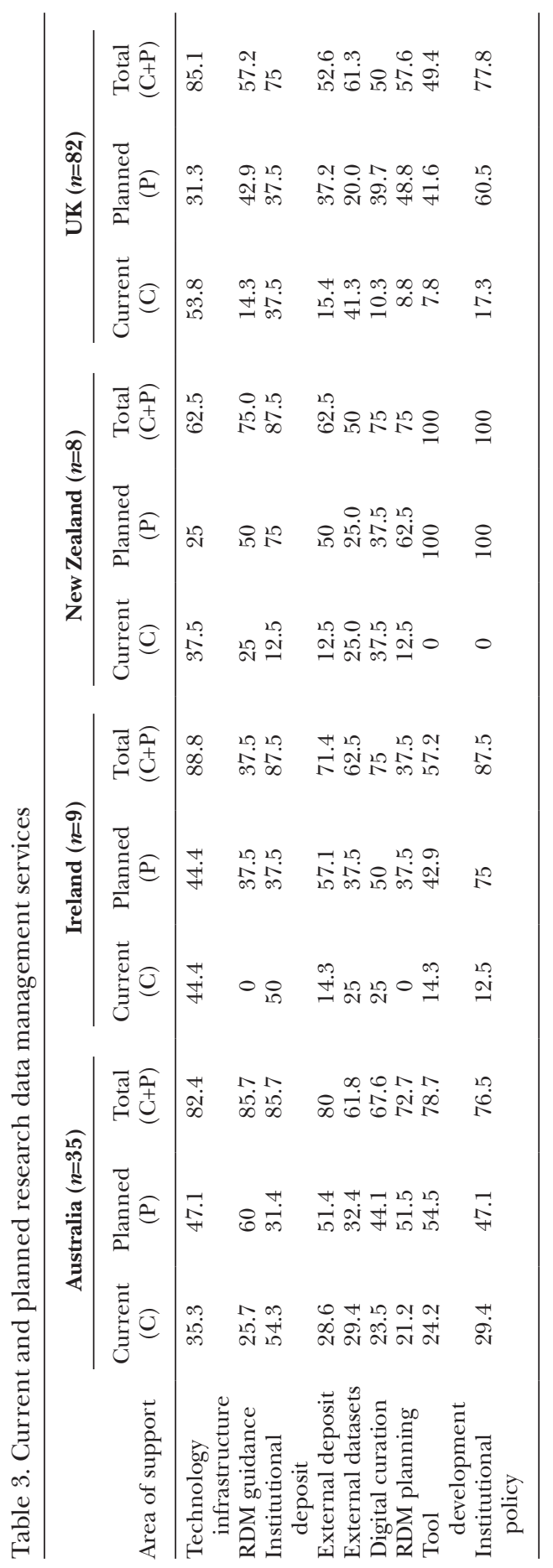



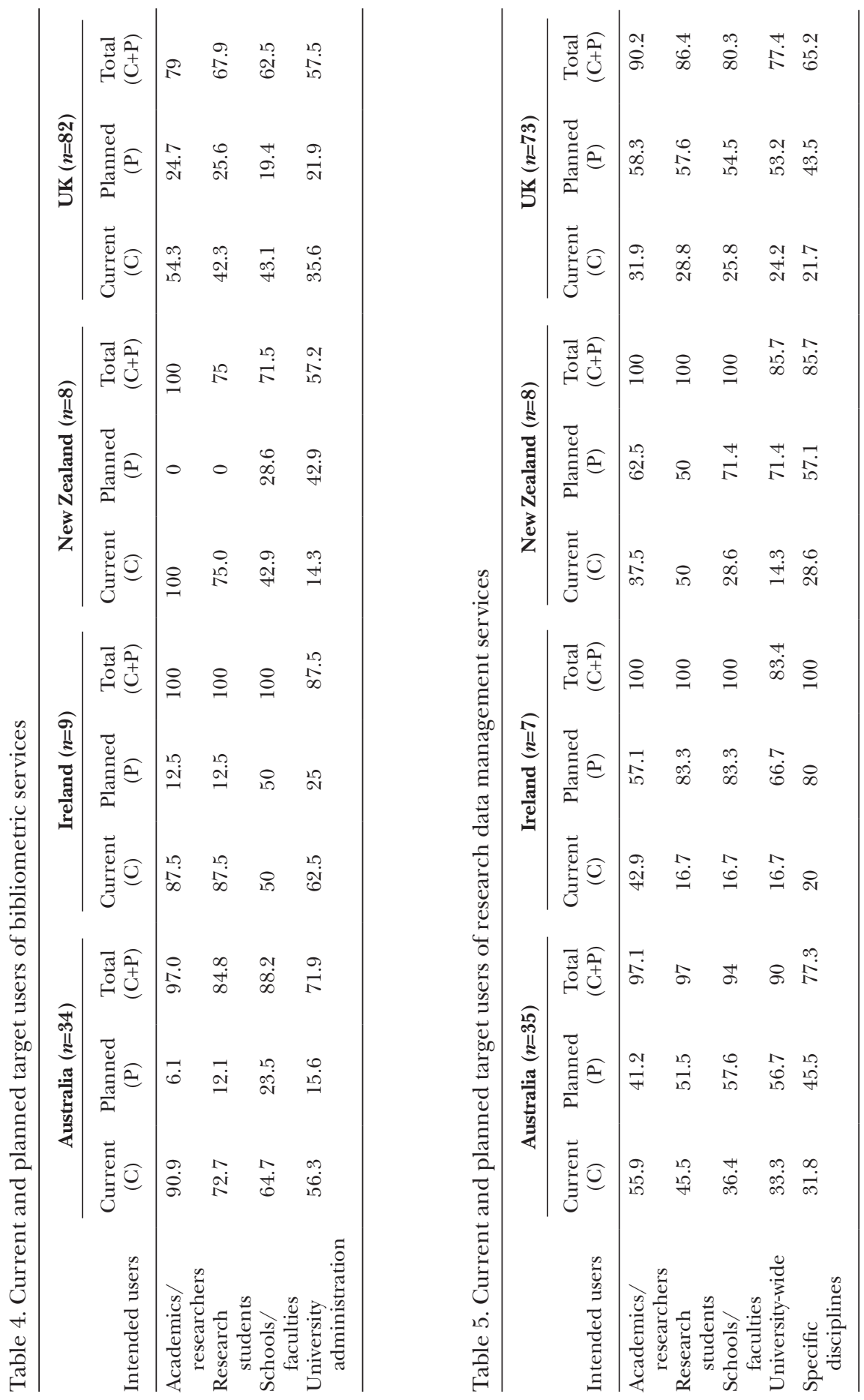
Another striking finding here was the number of libraries in the United Kingdom planning to offer RDM services to multiple user groups, which amounted to a significantly greater proportion than the U.K. libraries offering or planning to offer bibliometrics services. In all five categories, the number of libraries planning to offer these services was more than the libraries currently offering these services to specific user groups-a finding that presumably indicates the growing institutionalization of RDM in the academic culture of the United Kingdom. Similar arguments can be advanced for the other three countries. Table 5 provides a detailed percentage breakdown of current and planned target users of research data management services by user group and by country.

\section{Constraints on Service Development}

In any organization, initiation and development of a new or improved service generally rely on many different factors, which can include the availability of proper funding, in-house competency to deliver the service, persistence of demand for the service, and management support. Research support services around bibliometrics and RDM are also typical of the kinds of services that may require very specific individual expertise, and consequently a lack of such expertise can drastically hinder the offering of such services. Respondents were invited to specify any factors constraining the development of bibliometric services and RDM services in their library, selecting from the following list all factors that applied, with the option in each case to specify other factors if applicable:

- Bibliometrics/RDM is not a priority for your library.

- Bibliometrics/RDM is not perceived by others as a library role.

- There are different levels of demand across academic departments/ schools.

- There are different specialist needs across disciplines and subjects.

- Library staff require additional knowledge or skills.

- Library staff require additional confidence to work in this area.

Figure 2 summarizes the factors perceived as constraining the development of bibliometric services, showing the percentages of libraries in each country that selected each factor. With the exception of respondents from New Zealand, most library participants in the four countries regarded a need for additional knowledge and skills and a need for confidence (which typically accompanies such knowledge and skills) as constraints. Many libraries also identified different levels of demand among academic departments and different needs across disciplines and subjects as factors affecting service development, though these factors were less frequently selected by U.K. libraries. Interestingly, a substantial minority of U.K. libraries (40 libraries or 46.5 percent of respondents answering the question) indicated that bibliometric support was not a service priority for their library. 


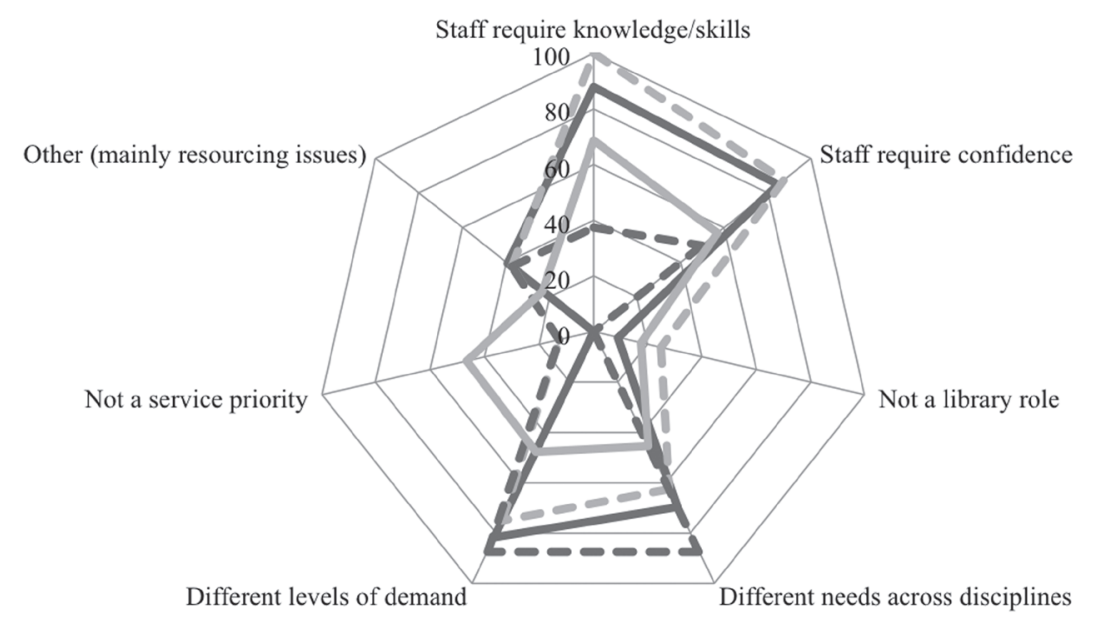

Australia $(\mathrm{n}=33) \quad-$ Ireland $(\mathrm{n}=8) \quad \longrightarrow$ New Zealand $(\mathrm{n}=8) \quad \mathrm{UK}(\mathrm{n}=86)$

Figure 2. Constraints on developing bibliometric services.

Figure 3 summarizes the perceived constraints on developing research data management services, showing that there was more consistency across all four countries in identifying the need for additional knowledge and skills, with confidence also an important factor here. Differences in demand and differing needs across disciplines were not so widely perceived as constraints here. In contrast to bibliometric support, there was more evidence here, particularly in Ireland and New Zealand, that service development might be constrained by perceptions on campus that RDM support was not a library role. In addition, RDM services were apparently not seen as a priority for around 40 percent of U.K. and Irish libraries.

Although resourcing was the most common additional constraint identified for both service areas, overall the percentages of respondents mentioning this or other issues were relatively low, except for Ireland. This contrasts with the concern expressed by Lewis (2010) about the scale of investment needed for institutions to manage their research data, when he specifically mentions the resource constraints under which U.K. university libraries typically work as a disincentive for involvement. In some cases, the availability to universities of national funding for e-research may have assisted resourcing of specialist support and services through initiatives such as the Australian National Data Service (ANDS) "Seeding the Commons" program (Treloar, 2009). Thus, within the United Kingdom, the University of Bath Library is involved in a project funded by the Joint Information Systems Committee (JISC) RDM program to embed good research data management practice in the institution (Lyon, 2012). 


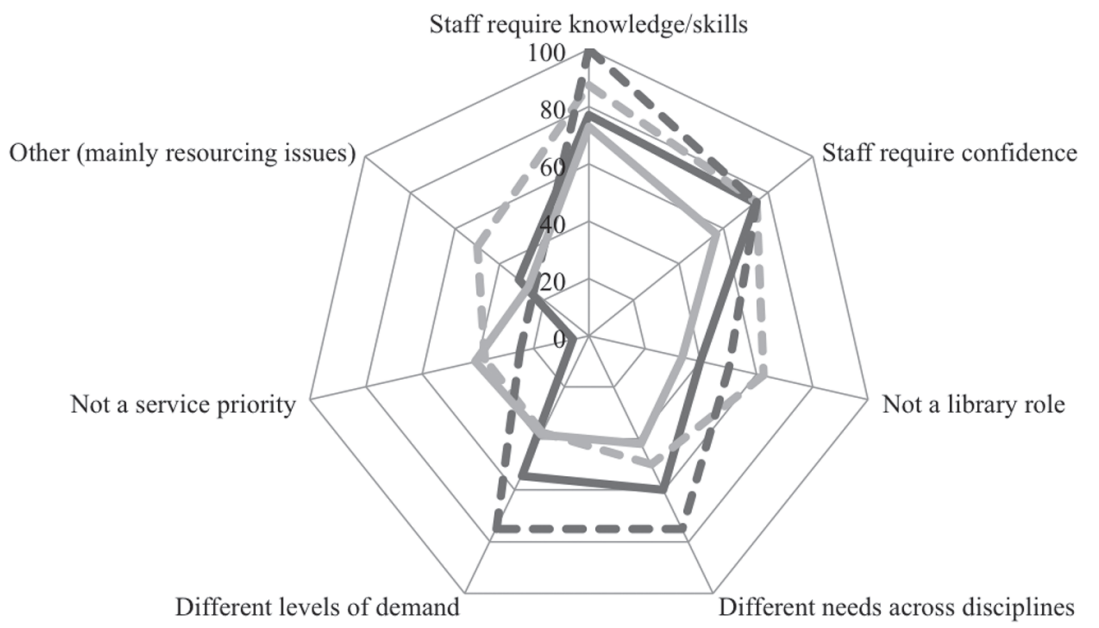

Australia $(\mathrm{n}=35) \rightarrow$ Ireland $(\mathrm{n}=8) \rightarrow$ New Zealand $(\mathrm{n}=8) \quad \mathrm{UK}(\mathrm{n}=81)$

Figure 3. Constraints on developing research data management services.

\section{Education for Service Delivery}

Most respondents reported that their staff learn their bibliometrics and RDM knowledge and skills on the job (around 80 percent across all four countries) or through in-house and self-training, with relatively low proportions reporting professional or other preservice education as the source of staff knowledge and skills. For bibliometrics, a sizable component of the "other" responses referred to training provided by vendors or suppliers. Two of the other responses for RDM training and education in Australia mentioned training through the national ANDS initiative (Treloar, 2009). All of the other responses, for both bibliometrics and RDM, referred in one way or another to these being areas of development, so education and training needs were still being assessed. Table 6 shows the percentages of responses for each source of education for both bibliometrics (Bib) and RDM. (Respondents were able to select more than one category in each case.)

In addition, respondents indicated the areas in which they perceived staff required additional knowledge and skills for libraries to offer bibliometrics and RDM services. Knowledge and skills required for bibliometrics are different from those required for RDM, so they are reported separately. The key competency needs identified for bibliometrics were related to understanding the different purposes and applications of bibliometrics and the different tools and techniques used. Skills in quantitative methods and techniques also rank quite highly (although one additional comment stated that only a basic level of competence in handling quantitative 
Table 6. Current staff education for bibliometrics and research data management support

\begin{tabular}{|c|c|c|c|c|c|c|c|c|}
\hline \multirow{2}{*}{$\begin{array}{l}\text { Source of staff } \\
\text { education or } \\
\text { training }\end{array}$} & \multicolumn{2}{|c|}{ Australia } & \multicolumn{2}{|c|}{ Ireland } & \multicolumn{2}{|c|}{ New Zealand } & \multicolumn{2}{|c|}{ UK } \\
\hline & $\begin{array}{c}\text { Bib } \\
(n=33)\end{array}$ & $\begin{array}{c}\text { RDM } \\
(\mathbf{n}=\mathbf{3 1})\end{array}$ & $\begin{array}{c}\text { Bib } \\
(n=8)\end{array}$ & $\begin{array}{l}\text { RDM } \\
(\mathbf{n}=7)\end{array}$ & $\begin{array}{c}\text { Bib } \\
(n=8)\end{array}$ & $\begin{array}{l}\text { RDM } \\
(\mathbf{n}=7)\end{array}$ & $\begin{array}{c}\mathrm{Bib} \\
(\mathrm{n}=67)\end{array}$ & $\begin{array}{c}\mathrm{RDM} \\
(\mathbf{n}=\mathbf{5 3})\end{array}$ \\
\hline $\begin{array}{l}\text { Prior to joining, } \\
\text { as part of their } \\
\text { LIS or other } \\
\text { education }\end{array}$ & 15.2 & 32.3 & 0 & 14.3 & 25.0 & 28.6 & 16.4 & 28.3 \\
\hline $\begin{array}{l}\text { Within the } \\
\text { library, } \\
\text { through in- } \\
\text { service training } \\
\text { or seminars }\end{array}$ & 84.8 & 64.5 & 75 & 42.9 & 100 & 57.1 & 47.8 & 49.1 \\
\hline Are self-trained & 69.7 & 71.0 & 100 & 71.4 & 50 & 57.1 & 80.6 & 60.4 \\
\hline Learn on-the-job & 84.8 & 80.6 & 100 & 85.7 & 100 & 85.7 & 80.6 & 79.2 \\
\hline $\begin{array}{l}\text { Library-funded } \\
\text { external } \\
\text { professional } \\
\text { development }\end{array}$ & 45.5 & 58.1 & 37.5 & 57.1 & 50 & 42.9 & 35.8 & 56.6 \\
\hline Other & 24.2 & 12.9 & 25 & 0 & 0 & 28.6 & 9 & 15.1 \\
\hline
\end{tabular}

data was needed), with a need for subject/disciplinary knowledge also recognized, but ranking below the other areas (see table 7). Comments in the "other" category here mainly elaborated on the specified areas; for example, reiterating the need to appreciate the context in which bibliometrics were being used, suggesting that scenarios or case studies could help staff understand purposes and motives, and noting the need to be able to evaluate and compare different bibliometric tools for purchase and use.

Not surprisingly, in view of the messages identified in the literature, the area identified as requiring the most development of knowledge and skills for library staff to work in RDM was data curation, closely followed by technical and ICT skills (see table 8). However, knowledge of research processes and (to a lesser extent) research methods also ranked highly. Key points that emerged from the seven Australian respondents who commented on "other" development needs for RDM were competency in metadata schemas for research data (mentioned three times) and the significance of the national legislative and policy context (reflected also in a reference to knowledge for creating data management plans); a need for skills in data discovery and research data interviews was also identified. Another Australian respondent specified "the correct protocols for citing research data" and "how to measure the impact of research data," indicating a potential degree of convergence between the two service areas of bibliometrics and RDM. The three U.K. libraries identifying "other" needs 
Table 7. Knowledge and skills needed for bibliometric services

\begin{tabular}{|c|c|c|c|c|}
\hline $\begin{array}{l}\text { Areas where additional knowledge } \\
\text { and skills needed }\end{array}$ & $\begin{array}{c}\text { Australia } \\
(n=35)\end{array}$ & $\begin{array}{l}\text { Ireland } \\
(n=9)\end{array}$ & $\begin{array}{c}\text { New } \\
\text { Zealand } \\
(n=8)\end{array}$ & $\underset{(n=76)}{\text { UK }}$ \\
\hline $\begin{array}{l}\text { Knowledge of different purposes and } \\
\text { applications of bibliometrics (e.g. } \\
\text { research evaluation, collection } \\
\text { development, benchmarking) }\end{array}$ & 85.7 & 88.9 & 87.5 & 88.2 \\
\hline $\begin{array}{l}\text { Skills in quantitative methods and } \\
\text { statistics }\end{array}$ & 82.9 & 77.8 & 62.5 & 82.9 \\
\hline $\begin{array}{l}\text { Knowledge of bibliometrics tools and } \\
\text { techniques (e.g. citation analyses, } \\
\text { impact factors and associated indices) }\end{array}$ & 88.6 & 77.8 & 87.5 & 97.4 \\
\hline $\begin{array}{l}\text { Required subject and/or disciplinary } \\
\text { knowledge }\end{array}$ & 60 & 44.4 & 50 & 26.3 \\
\hline Other & 14.3 & 22.2 & 0 & 6.6 \\
\hline
\end{tabular}

Table 8. Knowledge and skills needed for research data management services

\begin{tabular}{lcccc}
\hline $\begin{array}{l}\text { Areas where additional knowledge and } \\
\text { skills needed }\end{array}$ & $\begin{array}{c}\text { Australia } \\
(\boldsymbol{n}=\mathbf{3 5})\end{array}$ & $\begin{array}{c}\text { Ireland } \\
(\boldsymbol{n}=\mathbf{9})\end{array}$ & $\begin{array}{c}\text { New } \\
\text { Zealand } \\
(\boldsymbol{n}=\mathbf{8})\end{array}$ & $\begin{array}{c}\text { UK } \\
(\boldsymbol{n}=\mathbf{7 1})\end{array}$ \\
\hline $\begin{array}{l}\text { Data curation skills } \\
\text { Technical and ICT skills }\end{array}$ & 94.3 & 88.9 & 100 & 87.3 \\
$\begin{array}{l}\text { Required subject and/or disciplinary } \\
\quad \text { knowledge }\end{array}$ & 50 & 88.9 & 87.5 & 76.1 \\
$\begin{array}{l}\text { Knowledge of research methods } \\
\text { Knowledge of research processes }\end{array}$ & 68.6 & 44.4 & 37.5 & 36.6 \\
Other & 77.1 & 66.7 & 50 & 71.8 \\
\hline
\end{tabular}

here mentioned quite different concerns, which elaborated on the specified knowledge and skills areas, including a sufficient level of disciplinary knowledge and understanding of individual researcher needs to be credible and effective sources of RDM support. The differing emphases here on the context of RDM may reflect the earlier development of national policy for RDM in Australia.

Table 9 shows percentages of responses from each country supporting the different options suggested for covering bibliometrics and RDM in both preparatory LIS education and continuing professional development. (For both preparatory education and continuing development, survey participants could select only one of the three specified responses.)

Given the explicit recognition of knowledge and skills gaps as a major constraint on service development, particularly in relation to RDM, it is not surprising that the majority of participants went on to indicate 
that they considered it necessary to add electives to preparatory LIS education programs to equip new professionals for delivering bibliometric and RDM services. Indeed, almost 40 percent of the total sample thought RDM should be part of the core curriculum for LIS, with only slightly fewer (around one-third) supporting bibliometrics as a core subject. We speculate that most respondents judged electives as appropriate here on the basis that not all practitioners will be working in these areas, which is reasonable in view of the fact that LIS programs typically provide a general education for all library sectors (not just academia), though it might also suggest a continuing perception of such services as not being part of the core portfolio. Very few respondents (seven in the case of bibliometrics and three in the case of RDM, all from the United Kingdom) considered there was no need for professional education in these areas.

For continuing professional development (i.e., in-service postqualification education or training for practitioners), the vast majority (around two-thirds of the total sample) favored externally provided education or training over in-house training and development provided by their own library or parent institution. Results were fairly consistent across the four countries with only minor variations in preferences expressed. The U.K. responses were again slightly out of line, with five libraries identifying no need for continuing education provision in bibliometrics, but only one respondent suggesting no need for provision related to RDM. None of the participants from the other three countries selected the "No" option. Participants were also asked to identify priority areas for staff training and education for research support services, under the headings "critical," "important," and "desired." Interestingly, training in bibliometrics and impact measures was more often identified as "critical" than education related to data management/curation and metadata, particularly in the United Kingdom, but both areas featured to a similar extent in responses for the "important" category. Another striking finding across the sample was the emphasis placed on understanding the research environment at both macro and micro levels, including research processes, methodologies, and workflows, as well as university and government agenda.

Overall, the results from the education and training questions have significant implications for LIS schools, signaling an important and urgent need for curriculum development in relation to initial professional education programs but also suggesting opportunities for short-course provision to meet continuing education and development needs. Viewed alongside the responses to questions about future plans and perceived constraints on service development, in addition to those on how existing practitioners had gained their specialist knowledge and skills (which showed almost 60 percent had participated in external development for RDM, but less than 40 percent for bibliometrics), the opportunities for professional development and training provision in bibliometrics look particularly promising. In addi- 


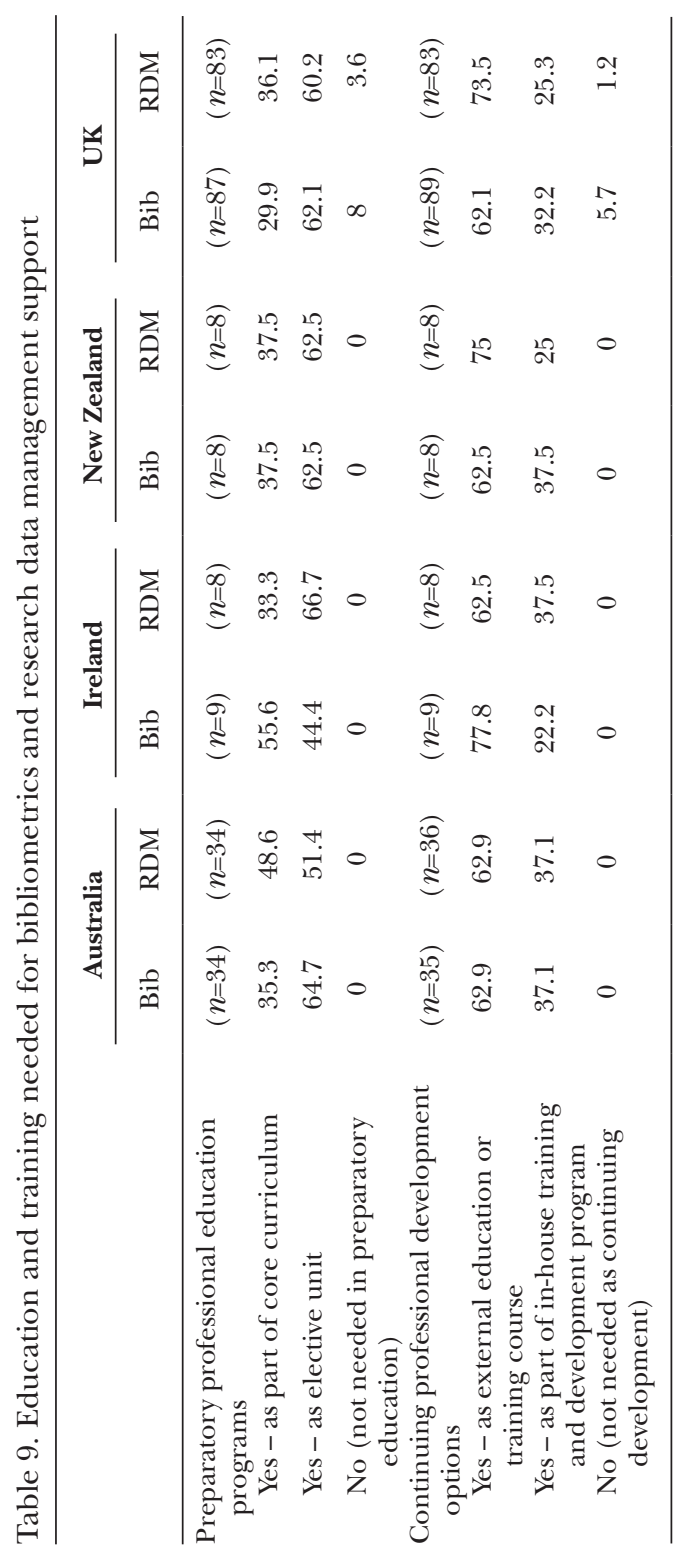


tion, the creation of modular continuing education or professional updating programs, combining units/courses covering bibliometrics and RDM with units/courses on research processes and methodologies, and different elements of the environmental context for library research support also warrants further exploration; such units or subunits could cover, for example, developments in e-research, data-intensive science, and digital humanities; scholarly communication and publishing; intellectual property and licensing; research assessment/evaluation; and higher education policy.

\section{Conclusions}

Bibliometric techniques have been used in information research and library practice over a long period but have gained renewed momentum with the development of national exercises to assess the quality of university research, the introduction of performance-based allocation of research funding, and the emergence of new measures and tools for research evaluation, reflecting the migration of scholarship to the web and the influence of social media. The focus of bibliometric activity in academic libraries has shifted from collection development to research evaluation and impact assessment for individual researchers, academic groups, organizational units and whole institutions, offering opportunities for strategic alignment of library services with institutional goals and development of new audiences and partnerships, notably with research administrators. Our study has confirmed the growing involvement of academic libraries within the four countries surveyed in providing bibliometric support using citation reports and impact calculations for academic units and at the institutional level as well as training and guidance for individual researchers and research groups, but evidence from the literature indicates that there are significant opportunities for further engagement in trend analysis, publishing strategies, faculty reviews, grant writing, and job applications.

Support for research data management represents a newer and arguably more challenging development in the library service portfolio, driven by advances in computing infrastructure and networking technologies, the development of large-scale global interdisciplinary research collaborations, and public policy requirements for accountability, integrity and transparency. The involvement of academic libraries in e-science/e-research has been seen as a natural extension of their electronic resource management and digital stewardship responsibilities but also questioned because of the level of technical know-how and domain understanding required. Libraries have been able to connect RDM with historical and contemporary areas of professional practice, including materials selection, metadata creation and collection management; reference services, information literacy, and research consultation; and scholarly communication, open access, and institutional repositories. Moreover, many librarians have previous experience of building collections of locally sourced 
digital resources and facilitating access to externally sourced social science datasets that can inform policy and practice in dealing with locally generated research data across multiple disciplines.

Our research found lower levels of involvement in RDM at present than for bibliometrics among the libraries surveyed but plans for significant expansion of services that look set to be wide-ranging in the scope of support offered and audiences identified, with priority apparently assigned to assistance with technology, infrastructure and tools, support for data deposit in an institutional repository, and development of institutional policy to manage data. Evidence from the literature suggests that helping researchers to develop data management plans in line with funding requirements could be another fruitful area for early engagement but acknowledges that involvement in technical aspects of digital curation and developing tools to assist researchers manage their data are dependent on knowledge and skills that may not be present in the existing workforce.

Our study provides clear evidence that in many cases development of the types of specialized research support services investigated are constrained by knowledge and skills gaps among library staff and a lack of confidence surrounding their expected roles in both RDM and bibliometrics. While technical competencies in both bibliometrics and RDM scored highly among the areas where knowledge and skills were needed, our findings also demonstrate the importance of understanding the research environment at both macro and micro levels for providing effective services for research. The implications for LIS education and professional development thus extend beyond the focus on technological competences and domain/disciplinary knowledge that pervades existing literature on the subject. Academic librarians involved in research support need to understand governmental and institutional research agenda, including both national policy and local goals, to enable them to contribute to strategy and policy development and implementation. They also need an end-to-end understanding of academic and research processes, methods and workflows, to design and deliver appropriate interventions at different stages of the scholarly lifecycle, via embedded or "in context" service models. Our research also found almost universal support for incorporating RDM and bibliometrics into professional education programs, with around onethird of respondents suggesting the subjects should be part of the core curriculum.

Finally, the survey results suggest several areas for future research. First, it would useful to gain a longitudinal perspective on service evolution and innovation by conducting a follow-up survey after an interval of three years to track service developments and explore how planned services have evolved in practice and what other plans have emerged since the present study. The survey could also be extended to include other countries to enable further comparisons across countries and assess the impact of the 
national policy environment on the development of library research support. Second, it would be valuable to complement such a survey with more in-depth qualitative exploration of the factors driving, enabling, and/or restraining service development and delivery, which could examine issues such as perceptions of library roles in supporting research, relationships between librarians and others involved in the research cycle, and the competencies required to provide different types of RDM and bibliometric support. Such a study could also be used to produce case studies to share with library practitioners and LIS students. Finally, it would be useful to investigate the coverage of bibliometrics and RDM in LIS curricula, not only in specialist electives and concentrations, but also in core courses as part of the general education of library and information professionals for the "data decade."

\section{ACKNOWLEDGMENTS}

The authors acknowledge with thanks the financial support provided by the Information Studies Research Priority Area, Information Infrastructure Program, Faculty of Education, Charles Sturt University and in-kind contributions provided by the Information School, University of Sheffield. They are particularly grateful to Angharad Roberts, University of Sheffield, for her assistance with distribution of the survey to libraries in the United Kingdom and Ireland. They also gratefully acknowledge the time and effort contributed to the study by the participants and by colleagues who participated in the pilot testing and assisted with the design of the survey instrument.

\section{REFERENCES}

Adams, J. (2007). Bibliometrics, assessment and UK research. Serials, 20, 188-191. Retrieved October 22, 2012, from http:/ / uksg.metapress.com/content/10yj8m7h3e4ljcmw/fulltext.pdf

Aldrich, A. W. (2007). Following the phosphorous trail of research library mission statements into present and future harbors. In Sailing into the Future: Charting Our Destiny, ACRL 13th National Conference (pp. 304-316). Chicago, IL: American Library Association, Association of College and Research Libraries. Retrieved October 22, 2012, from http://www.ala.org/ acrl/conferences/confsandpreconfs/national/baltimore/baltimore

Amos, K., Mower, A., James, M. A., Weber, A., Yaffe, J., \& Youngkin, M. (2012). Exploring publishing patterns at a large research university: Implications for library practice. Evidence Based Library and Information Practice, 7(3), 32-50. Retrieved October 22, 2012, from http:/ / ejournals.library.ualberta.ca/index.php/EBLIP/article/view/17122/14266

Arizona State University. (2012). Citation research: How to find citation counts for your publications and how to find journal rankings such as impact factors. Retrieved October 22, 2012, from http://libguides.asu.edu/citation

Auckland, M. (2012). Re-skilling for research: An investigation into the roles and skills of subject and liaison librarians required to effectively support the evolving information needs of researchers. London: RLUK Research Libraries UK. Retrieved October 22, 2012, from http://www.rluk .ac.uk/content/re-skilling-research

Ball, R., \& Tunger, D. (2006). Bibliometric analysis - a new business area for information professionals in libraries? Support for scientific research by perception and trend analysis. Scientometrics, 66, 561-577. 
Barrett, J. (2012). UCD data management checklist. Dublin, Ireland: University College Dublin, The Library: Retrieved November 21, 2012, from https://www.ucd.ie/t4cms/Guide121.pdf Baughman, J. C. (1977). Towards a structural approach to collection development. College $\mathcal{E}^{\circ}$ Research Libraries, 38, 241-248.

Beck, S. E., \& Manuel, K. (2008). Practical research methods for librarians and information professionals. New York: Neal-Schuman.

Bennett, D. B., Leonard, M., \& Wrublewski, D. (2012). Comparing engineering departments across institutions: Gathering publication impact data in a short timeframe. Issues in Science and Technology Librarianship, 68. Retrieved October 22, 2012, from http://www.istl.org/ 12-winter/refereed2.html

Bent, M., Gannon-Leary, P., \& Webb, J. (2007). Information literacy in a researcher's learning life: Seven ages of research. New Review of Information Networking, 13, 81-99.

Bourg, C., Coleman, R., \& Erway, R. (2009). Support for the research process: An academic library manifesto. Dublin, OH: OCLC Research. Retrieved October 22, 2012, from http://www .oclc.org/content/dam/research/publications/library/2009/2009-07.pdf

Broadus, R. N. (1977). The applications of citation analyses to library collection building. Advances in Librarianship, 7, 299-355.

Brownlee, R. (2009). Research data and repository metadata: Policy and technical issues at the University of Sydney Library. Cataloging E Classification Quarterly, 47, 370-379.

Burke, L. (2008). Models of reference services in Australian academic libraries. Journal of Librarianship and Information Science, 40, 269-286.

Carlson, J., \& Kneale, R. (2011). Embedded librarianship in the research context: Navigating new waters. College $\mathcal{E}$ Research Libraries News, 72, 167-170. Retrieved October 22, 2012, from http://crln.acrl.org/content/72/3/167.full

Carlson, J. R., \& Garritano, J. R. (2010). E-science, cyberinfrastructure, and the changing face of scholarship: Organizing for new models of research support at the Purdue University Libraries. In S. Walter \& K. Williams (Eds.), Staffing, sustaining, and advancing the academic library in the 21st century (pp. 234-269). Chicago, IL: Association of College and Research Libraries.

Case, D. (2012). Looking for information: A survey of research on information seeking, needs and behaviour (3rd ed.). Bingley, England: Emerald.

Choudhury, G. S. (2008). Case study in data curation at Johns Hopkins University. Library Trends, 57, 211-220.

Connaway, L. S., \& Powell, R. R. (2010). Basic research methods for librarians (5th ed.). Westport. CT: Libraries Unlimited.

Corrall, S. (2012). Roles and responsibilities: Libraries, librarians and data. In G. Pryor (Ed.), Managing research data (pp. 105-133). London: Facet.

Cotta-Schønberg, M. (2007). The changing role of the subject specialist. Liber Quarterly, 17 (3/4). Retrieved October 22, 2012, from http://liber.library.uu.nl/index.php/lq/article/ view/7890/8111

Davis, M., Wilson, C. S., \& Horn, H. (2005). Informing decision-making in libraries: Informetric research as input to LIS education and practice. Australian Academic and Research Libraries, 36, 195-213. Retrieved October 22, 2102, from http://www.alia.org.au/publishing/ aarl/36.4/davis.pdf

De Bellis, N. (2009). Bibliometrics and citation analysis: From the Science Citation Index to cybermetrics. Lanham, MD: Scarecrow Press.

Delasalle, J. (2012). Research evaluation: Bibliometrics and the librarian. SCONULFocus, 53, 1519. Retrieved October 22, 2012, from http://www.sconul.ac.uk/publications/newsletter/ $53 / 5 . p d f$

Delserone, L. M. (2008). At the watershed: Preparing for research data management and stewardship at the University of Minnesota Libraries. Library Trends, 57, 202-210.

Drott, M. C., Mancall, J., \& Griffith, B. C. (1979). Bradford's Law and libraries: Present applications-potential promise. ASLIB Proceedings, 31, 296-304.

Drummond, R., \& Wartho, R. (2009). RIMS: The Research Impact Measurement Service at the University of New South Wales. Australian Academic Eं Research Libraries, 40, 76-87. Retrieved October 22, 2012, from http://www.alia.org.au/publishing/aarl/40/ARRL .Vol40.No2.2009.pdf 
Duranceau, E. F. (2008). The "Wealth of Networks" and institutional repositories: MIT, DSpace, and the future of the scholarly commons. Library Trends, 57, 244-261.

Florance, P. (2006). GIS collection development within an academic library. Library Trends, 55, 222-234. Retrieved October 22, 2012, from https://www.ideals.illinois.edu/ handle/2142/3680

Fonseca, A. J., \& Viator, V. P. (2009). Escaping the island of lost faculty: Collaboration as a means of visibility. Collaborative Librarianship, 1, 81-90. Retrieved October 22, 2012, from http://collaborativelibrarianship.org/index.php/jocl/article/view/23/14

Freiburger, G., \& Kramer, S. (2009). Embedded librarians: One library's model for decentralized service. Journal of the Medical Library Association, 97, 139-142. Retrieved October 22, 2012, from http://www.ncbi.nlm.nih.gov/pmc/articles/PMC2670204/

Friedlander, A., \& Adler, P. (2006) To stand the test of time: Long-term stewardship of digital data sets in science and engineering, a report to the National Science Foundation from the ARL Workshop on New Collaborative Relationships: The Role of Academic Libraries in the Digital Data Universe. Washington, D.C.: Association of Research Libraries. Retrieved October 22, 2012, from http://www.arl.org/bm doc/digdatarpt.pdf

Fulton, B., Botticelli, P., \& Bradley, J. (2011). DigIn: A hands-on approach to a digital curation curriculum for professional development. Journal of Education for Library and Information Science, 52, 95-109.

Gabridge, T. (2009). The last mile: Liaison roles in curating science and engineering research data. Research Library Issues, 265, 15-21. Retrieved October 22, 2012, from http://www.arl .org/bm doc/rli-265-gabridge.pdf

Garritano, J. R., \& Carlson, J. R. (2009). A subject librarian's guide to collaborating on e-science projects. Issues in Science and Technology Librarianship, 57. Retrieved October 22, 2012, from http://www.istl.org/09-spring/refereed2.html\#15

Gibbs, C., \& Sergeant, K. (2009, January). Opportunity, not hard work: Scripted solutions to solving our bibliometric nightmare. Paper presented at Information Online 2009: ALIA 14th Exhibition and Conference, Sydney. Retrieved October 22, 2012, from http://conferences. alia.org.au/online2009/docs/PresentationB6.pdf

Gold, A. (2007). Cyberinfrastructure, data, and libraries, part 2. Libraries and the data challenge: Roles and actions for libraries. D-Lib Magazine, 13(9/10). Retrieved October 22, 2012, from http://www.dlib.org/dlib/september07/gold/09gold-pt2.html

Gumpenberger, C., Wieland, M., \& Gorraiz, J. (2012). Bibliometric practices and activities at the University of Vienna. Library Management, 33, 174-183.

Harris-Pierce, R. L., \& Liu, Y. Q. (2012). Is data curation education at library and information science schools in North America adequate? New Library World, 113(11/12), 598-613.

Harvey, R. (2010). Digital curation: A how-to-do-It manual. New York: Neal-Schuman.

Heath, F. (2011). Library assessment: The way we have grown. Library Quarterly, 81, 7-25.

HEFCE (2009). Report on the pilot exercise to develop bibliometric indicators for the Research Excellence Framework. Bristol, England: Higher Education Funding Council for England. Retrieved October 22, 2012, from http://www.hefce.ac.uk/media/hefce1/pubs/ hefce/2009/0939/09_39.pdf

HEFCE (2011). Analysis of data from the pilot exercise to develop bibliometric indicators for the REF: The effect of using normalised citation scores for particular staff characteristics. Bristol, England: Higher Education Funding Council for England. Retrieved October 22, 2012, from http:// www.hefce.ac.uk/media/hefce1/pubs/hefce/2011/1103/11_03.pdf

Hendrix, D. (2010). Tenure metrics: Bibliometric education and services for academic faculty. Medical Reference Services Quarterly, 29, 183-189.

Henty, M. (2008). Developing the capability and skills to support e-research. Ariadne, 55. Retrieved October 22, 2012, from http://www.ariadne.ac.uk/issue55/henty

Herther, N. (2009). Research evaluation and citation analysis: Key issues and implications. The Electronic Library, 27, 361-375.

Hey, T., \& Hey J. (2006). E-science and its implications for the library community. Library Hi Tech, 24, 515-528.

HLG (2010) High Level Expert Group on Scientific Data. Riding the wave: How Europe can gain from the rising tide of scientific data. Brussels: European Commission. Retrieved October 22, 2012, from http://cordis.europa.eu/fp7/ict/e-infrastructure/docs/hlg-sdi-report.pdf

Holland, M. (2006). Serving different constituencies: Researchers. In P. Dale., M. Holland, \& M. Matthews (Eds.), Subject librarians: Engaging with the learning and teaching environment (pp. 131-147). Aldershot, England: Ashgate. 
Houser, R. (2006). Building a library GIS service from the ground up. Library Trends, 55, 315-326. Retrieved October 22, 2012, from https://www.ideals.uiuc.edu/handle/2142/3681

Hswe, P., \& Holt, A. (2011). Joining in the enterprise of response in the wake of the NSF data management planning requirement. Research Library Issues, 274, 11-17. Retrieved October 22, 2012, from http://publications.arl.org/17gcns.pdf

Joint, N. (2008). Bemused by bibliometrics: Using citation analysis to evaluate research quality. Library Review, 57, 346-357.

Jones-Evans, A. (2005). Bangor university library service: An update. Journal of Librarianship and Information Science, 37, 115-117.

Kear, R., \& Colbert-Lewis, D. (2011). Citation searching and bibliometric measures. College $\mathcal{E}$ Research Libraries News, 72, 470-474. Retrieved October 22, 2012, from http://crln.acrl .org/content/72/8/470.long

Keralis, S. D. C. (2012). Data curation education: A snapshot. In L. Jahnke, A. Asher, \& S. D. C. Keralis. The problem of data (pp. 32-43). Washington, D.C.: Council on Library and Information Resources. Retrieved October 22, 2012, from http://www.clir.org/pubs/ reports/pub154/pub154.pdf

Lage, K., Losoff, B., \& Maness, J. (2012). Receptivity to library involvement in scientific data curation: A case study at the University of Colorado Boulder. Portal: Libraries and the Academy, 11, 915-937.

Lewis, M. (2010). Libraries and the management of research data. In S. McKnight (Ed.), Envisioning future academic library services: Initiatives, ideas and challenges (pp. 145-168). London: Facet.

Line, M. B. (1978). Rank lists based on citations and library use as indicators of journal usage in individual libraries. Collection Management, 2, 313-316.

Lyon, L. (2007). Dealing with data: Roles, rights, responsibilities and relationships. Bath, England: UKOLN. Retrieved October 22, 2012, from http://www.ukoln.ac.uk/ukoln/staff/e.j.lyon/ reports/dealing_with_data_report-final.pdf

Lyon, L. (2012). The informatics transform: Re-engineering libraries for the data decade. International Journal of Digital Curation, 7(1), 126-138. Retrieved October 22, 2012, from http://www.ijdc.net/index.php/ijdc/article/view/210/279

MacColl, J. (2010). Library roles in university research assessment. Liber Quarterly, 20, 152168. Retrieved October 22, 2012, from http://liber.library.uu.nl/index.php/lq/article/ view/7984/8299

MacColl, J., \& Jubb, M. (2011). Supporting research: Environments, administration and libraries. Dublin, OH: OCLC Research. Retrieved October 22, 2012, from http://www.oclc.org/ resources/research/publications/library/2011/2011-10.pdf

Macdonald, S., \& Martinez, L. (2005). Supporting local data users in the UK academic community. Ariadne, 44. Retrieved October 22, 2012, from http://www.ariadne.ac.uk/issue44/ martinez

Macdonald, S., \& Uribe, L. M. (2008). Libraries in the converging world of open data, e-research, and Web 2.0. Online, 32(2), 36-40. Retrieved March 18, 2013, from http:// repository.jisc.ac.uk/227/1/Online_mar08.pdf

Macquarie University. (2012). Research metrics: Research metrics allows you to measure the impact of your research and publications. Retrieved October 22, 2012, from http://libguides.mq.edu .au/Research-Metrics

Marcum, D. B., \& George, G. (Eds.), (2010). The data deluge: Can libraries cope with e-science? Santa Barbara, CA: Libraries Unlimited.

Mays, R., Tenopir, C., \& Kaufman, P. (2010). Lib-Value: Measuring value and return on investment of academic libraries. Research Library Issues, 271, 36-40. Retrieved October 22, 2012, from http://www.arl.org/bm doc/rli271-libvalue.pdf

McNeill, P., \& Chapman, S. (2005). Research methods (3rd ed.). New York: Routledge.

Nicholas, D., Rowlands, I., Jubb, M., \& Jamali, H. R. (2010). The impact of the economic downturn on libraries: With special reference to university libraries. Journal of Academic Librarianship, 36, 376-382.

NSF (2007). Cyberinfrastructure vision for 21st century discovery. Arlington, VA: National Science Foundation, Cyberinfrastructure Council. Retrieved March 18, 2013, from http://www. nsf.gov/pubs/2007/nsf0728/nsf0728.pdf

Oakleaf, M. (2010). The value of academic libraries: A comprehensive research review and report. Chicago, IL: Association of College and Research Libraries. Retrieved October 22, 2012, from http://www.ala.org/ala/mgrps/divs/acrl/issues/value/val_report.pdf 
Pan, R., \& Breen, E. (2011, April). MyRI: An open access bibliometrics toolkit - collaboration in research skills support. Paper presented at LILAC 2011: Librarians' Information Literacy Annual Conference, London. Retrieved October 22, 2012, from http://www.slideshare .net/infolit_group/pan-breen

Pendlebury, D. (2008). Using bibliometrics in evaluating research. White Paper. Philadelphia, PA: Thomson Reuters. Retrieved October 22, 2012, from http://thomsonreuters.com/ content/science/pdf/ssr/training/UsingBibliometricsinEval_WP.pdf

Peters, C., \& Dryden, A. R. (2011). Assessing the academic library's role in campus-wide research data management: A first step at the University of Houston. Science $\mathcal{E}$ Technology Libraries, 30, 387-403

Pickard, A. J. (2007). Research methods in information. London: Facet.

Pryor, G. (Ed.), (2012). Managing research data. London: Facet.

Pryor, G., \& Donnelly, M. (2009). Skilling up to do data: Whose role, whose responsibility, whose career? International Journal of Digital Curation, 4(2), 158-170. Retrieved October 22, 2012, from http://www.ijdc.net/index.php/ijdc/article/view/126

Qin, J., D’Ignazio, J., Oakleaf, M., Crowston, K., Wiggins, A., \& Kuehn, A. (2010, December). Educating escience librarians. Poster presented at Participation and Practice: Growing the Curation Community through the Data Decade, 6th International Digital Curation Conference, Chicago, IL. Retrieved October 22, 2102, from http://www.dcc.ac.uk/events/ conferences/6th-international-digital-curation-conference/posters

Rambo, N. (2010). Changes in research libraries as a result of e-science initiatives: A snapshot. In D. B. Marcum \& G. George (Eds.), The data deluge: Can libraries cope with e-science? (pp. 43-60). Santa Barbara, CA: Libraries Unlimited.

Ray, J. (2009). Sharks, digital curation, and the education of information professionals. Museum Management and Curatorship, 24, 357-368.

Renear, A. H., Dolan, M., Trainor, K., \& Muñox, T. (2010, February). Extending an LIS data curation curriculum to the humanities: Selected activities and observations. Poster presented at iConference 2010, Champaign, IL. Abstract retrieved October 22, 2012, from https://www .ideals.illinois.edu/handle/2142/15061

Rice, R., \& Haywood, J. (2011). Research data management initiatives at University of Edinburgh. International Journal of Digital Curation, 6(2), 232-244. Retrieved October 22, 2012, from http://www.ijdc.net/index.php/ijdc/article/view/194/259

RIN. (2007). Research Information Network \& Consortium of Research Libraries. Researchers' use of academic libraries and their services: A report commissioned by the Research Information Network and the Consortium of Research Libraries. London: Research Information Network. Retrieved October 22, 2012, from http://www.rin.ac.uk/system/files/attachments/Researchers -libraries-services-report.pdf

RIN. (2011). Research Information Network \& Research Libraries UK. The value of libraries for research and researchers: $A$ RIN and RLUK report. London: Research Information Network. Retrieved October 22, 2012, from http://www.rluk.ac.uk/content/value-libraries-research -and-researchers

Roemer, R. C., \& Borchadt, R. (2012). From bibliometrics to altmetrics: A changing scholarly landscape. College Eं Research Libraries News, 73, 596-600. Retrieved October 22, 2012, from http://crln.acrl.org/content/73/10/596.full

Schonfield, R. C., \& Housewright, R. (2010). Faculty survey 2009: Key strategic insights for libraries, publishers, and societies. New York: Ithaka Strategic Consulting and Research. Retrieved October 22, 2012, from http://www.sr.ithaka.org/research-publications/faculty-survey-2009

Schottlaender, B. E. C. (2010). An idiosyncratic perspective on the history and development at the University of California, San Diego, of support for Cyberinfrastructure-enabled e-science (99-112). In D. B. Marcum \& G. George (Eds.), The data deluge: Can libraries cope with e-science? (pp. 43-60). Santa Barbara, CA: Libraries Unlimited.

Schrader, A. M. (1981). Teaching bibliometrics. Library Trends, 30, 151-172. Retrieved October 22, 2012, from https://www.ideals.illinois.edu/handle/2142/7192

Shumaker, D. (2012). The embedded librarian: Innovative strategies for taking knowledge where it's needed. Medford, NJ: Information Today.

Soehner, C., Steeves, C., \& Ward, J. (2010). e-Science and data support services: A study of ARL member institutions. Washington, D.C.: Association of Research Libraries. Retrieved October 22, 2012, from http://www.arl.org/bm doc/escience_report2010.pdf

Stanton, J. M., Kim, Y., Oakleaf, M., Lankes, R. D., Gandel, P., Cogburn, D., \& Liddy, E. D. 
(2011). Education for eScience professionals: Job analysis, curriculum guidance, and program considerations. Journal of Education for Library and Information Science, 52, 79-94.

Steinhart, G. (2006). Libraries as distributors of geospatial data: Data management policies as tools for managing partnerships. Library Trends, 55, 264-284. Retrieved October 22, 2012, from https://www.ideals.uiuc.edu/handle/2142/3689

Swan, A. (2011). Institutional repositories - Now and next. In P. Dale, J. Beard., \& M. Holland (Eds.), University libraries and digital learning environments (pp. 119-133). Farnham, England: Ashgate.

Swan, A., \& Brown, S. (2008). The skills, role and career structure of data scientists and curators: An assessment of current practice and future needs. Truro, England: Key Perspectives. Retrieved October 22, 2012, from http://www.jisc.ac.uk/publications/documents/dataskillscareers finalreport.aspx

Thomas, J. (2011). Future-proofing: The academic library's role in e-research support. Library Management, 32, 37-47.

Town, J. S. (2011). Value, impact, and the transcendent library: Progress and pressures in performance measurement and evaluation. Library Quarterly, 81, 111-125.

Treloar, A. (2009). Design and implementation of the Australian National Data Service. International Journal of Digital Curation, 4(1), 125-137. Retrieved October 22, 2012, from http://ijdc.net/index.php/ijdc/article/view/107/83

University of Pittsburgh. (2012). Citation searching and bibliometric measures: A discussion on topics such as the h-index, Eigenfactor, impact factor, Journal Citation Reports, and other tools. Retrieved October 22, 2012, from http://pitt.libguides.com/bibliometrics

University of North Texas. (2011). UNT receives more than $\$ 800,000$ to investigate needs in archiving research data. Retrieved October 22, 2012, from http://untsystem.edu/ news/2011/August/11-08-09-arch-res-data.htm

Varvel, V. E., Bammerlin, E., \& Palmer, C. L. (2012). Education for data professionals: A study of current courses and programs. Poster presented at the iConference 2012: Proceedings of the 2012 iConference (pp. 527-529). NewYork: Association for Computing Machinery.

von Ungern-Sternberg, S. (1998). Teaching bibliometrics. Journal of Education for Library and Information Science, 39, 76-80.

Wallace, D. P., \& Van Fleet, C. (2012). Knowledge in action: Research and evaluation in library and information science. Santa Barbara, CA: Libraries Unlimited.

Walters, T. O. (2009). Data curation program development in U.S. universities: The Georgia Institute of Technology example. International Journal of Digital Curation, 3(4), 83-92. Retrieved October 22, 2012, from http://www.ijdc.net/index.php/ijdc/article/ viewFile/136/153

Warr, R. B. (1983). Bibliometrics: A model for judging quality. Collection Building, 5(2), 29-34.

Webb, J., Gannon-Leary, P., \& Bent, M. (2007). Providing effective library services for research. London: Facet.

Westra, B. (2010). Data services for the sciences: A needs assessment. Ariadne, 64. Retrieved October 22, 2012, from http://www.ariadne.ac.uk/issue64/westra/

Witt, M. (2008). Institutional repositories and research data curation in a distributed environment. Library Trends, 57, 191-201.

Whitten, J., \& Bentley, L. (2007). Systems analysis and design methods (7th ed.). Boston, MA: McGraw-Hill.

Wildemuth, B. M. (2009). Applications of social research methods to questions in information and library science. Westport, CT: Libraries Unlimited.

Wong, G. K. W. (2009). Exploring research data hosting at the HKUST institutional repository. Serials Review, 35, 125-132.

Wood, E. J., Miller, R., \& Knapp, A. (2007). Beyond survival: Managing academic libraries in transition. Westport, CT: Libraries Unlimited.

Yakel, E., Conway, P., Hedstrom, M., \& Wallace, D. (2011). Digital curation for digital natives. Journal of Education for Library and Information Science, 52, 23-31.

Young, H., \& Lund, P. (2008) Reflections on a benchmarking survey of research support provided by 1994 Group libraries. SCONUL Focus, 43, 51-56. Retrieved October 22, 2012, from http://www.sconul.ac.uk/publications/newsletter/43/14.pdf

Zhao, D. (2011). Bibliometrics and LIS education: How do they fit together? [Panel proposal]. Proceedings of the American Society for Information Science and Technology: ASIST 2011, 48, 1-4. 
Sheila Corrall is professor and chair of the Library and Information Science Program in the School of Information Sciences at the University of Pittsburgh, where she teaches courses on research methods and academic libraries. Her research interests include the application of business management concepts to library and information services; evolving roles and competencies of library and information workers; and strategic development of information literacy. She worked at the University of Sheffield Information School from 2004 to 2012 and was head of the iSchool for four years. She previously worked in public, special, national, and academic libraries, including ten years in professional and management roles at The British Library and thirteen years as director of library, information and academic services at three universities in the UK. She is a former president of the Chartered Institute of Library and Information Professionals (CILIP) and currently serves on the editorial boards of five international journals.

Mary Anne Kennan is a senior lecturer in the School of Information Studies at Charles Sturt University, where she teaches courses on the digital environment, research data management and research methods. Her research interests build on her $2008 \mathrm{PhD}$, which focused on scholarly communication, institutional repositories, and open access, moving into the broader areas of e-research and research data management, including the practices of sharing and collaboration. Other recent investigations include the management and sharing of volunteer-collected data. Her previous experience includes twenty-five years working in libraries and the information world, including serving as director of the Frank Lowy Library at the Australian Graduate School of Management. She has also taught at the University of New South Wales and the University of Technology Sydney. She is joint editor of Australian Academic and Research Libraries and serves on the editorial board of the International Journal of Actor-Network Theory and Technological Innovation.

Waseem Afzal is a lecturer in the School of Information Studies at Charles Sturt University, where he teaches courses in strategic library management, knowledge management, project management in information agencies, and web studies. His research interests include human information behavior, the management of information organizations, e-commerce, the economics of information, and library and information science education. He earned his $\mathrm{PhD}$ in library and information science and his masters in business administration at Emporia State University, Emporia, Kansas, and his MCom (with an emphasis in finance) from the University of Punjab, Pakistan. His recent publications include the book Management of Information Organizations (published by Chandos in 2012), which offers a multidisciplinary perspective on the theory and practice of management for professionals working in libraries, museums, the media industry, publishing companies, and other information-centered organizations. 